Accepted refereed manuscript of:

Gavriilidis K, Kallinterakis V \& Tsalavoutas I (2016) Investor Mood, Herding and the Ramadan Effect, Journal of Economic Behavior and Organization, 132 (Supplement), pp. 23-38.

DOI: $\underline{10.1016 / j . j e b o .2015 .09 .018}$

(C) 2015, Elsevier. Licensed under the Creative Commons AttributionNonCommercial-NoDerivatives 4.0 International http://creativecommons.org/licenses/by-nc-nd/4.0/ 


\title{
Investor Mood, Herding and the Ramadan Effect
}

\author{
Konstantinos Gavriilidis
}

Vasileios Kallinterakis

Ioannis Tsalavoutas*

September, 2015

\section{Acknowledgements}

We gratefully acknowledge helpful comments received from three anonymous reviewers, one of the guest-editors, Basel Awartani, Fotini Economou, Christodoulos Louca, Vasileios Pappas, the participants of the 4th Islamic Banking and Finance Conference (Lancaster, 2014), of the Spring 2015 Multinational Finance Society Conference (Larnaca, Cyprus) and the $22^{\text {nd }}$ Annual Multinational Finance Society Conference (Halkidiki, June 2015).

* Corresponding author.

Konstantinos Gavriilidis is at the University of Stirling (Address: Stirling Management School, Accounting and Finance Division, FK9 4LA, Scotland, UK. E-mail: Konstantinos.Gavriilidis@stir.ac.uk).

Vasileios Kallinterakis is at the University of Liverpool (Address: University of Liverpool Management School, Chatham Building, Chatham Street, Liverpool L69 7ZH, United Kingdom E-mail address: V.Kallinterakis@liverpool.ac.uk).

Ioannis Tsalavoutas is at the University of Glasgow (Adam Smith Business School, West Quadrangle, Main Building, Room G683, University Avenue, Glasgow, G12 8QQ, Scotland, UK. E-mail: Ioannis.Tsalavoutas@glasgow.ac.uk). 


\title{
Investor Mood, Herding and the Ramadan Effect
}

\begin{abstract}
In view of evidence linking herding and social mood, we examine whether the positive mood documented during Ramadan translates into higher herding compared to non-Ramadan days. Drawing on a sample of seven majority Muslim countries, we report significant herding during Ramadan in most of our sample markets. Additionally, we show that herding appears significantly stronger within rather than outside Ramadan for most tests whereby its significance is manifested on both Ramadan- and non-Ramadan-days. Overall, herding significance within/outside Ramadan exhibits some variation in its levels across markets in relation to variables reflective of market states, both domestically (market returns; market volume) and internationally (US market returns; US investors' sentiment; global financial crisis) market states.
\end{abstract}

Keywords: herding; social mood; Ramadan.

JEL Classification: G02; G10; G15. 


\section{Introduction}

Religion is identified in several studies as a key factor underlying aspects of the economic and financial environment. From individual investors' perspective, religion has been found to affect the propensity to save (Guiso et al., 2003; Renneboog and Spaenjers, 2012), the decision to invest in stocks (Renneboog and Spaenjers, 2012) and risk-attitudes (Miller and Hoffmann, 1995; Barsky et al., 1997; Hilary and Hui, 2009; Kumar, 2009; Kumar et al., 2011). From an aggregate market perspective, religion has been shown to affect IPOunderpricing (Kumar et al., 2011), economic growth (Barro and McCleary, 2003) and creditor protection (Stulz and Williamson, 2003).

An area that has recently witnessed much research interest is that of investors' mood and how the latter is shaped by religious occasions. In general, the evidence suggests that mood and emotions play an important role in investor behavior. ${ }^{1}$ In fact, Shu (2010) argues that the higher the complexity of a decision and the uncertainty of its outcome, the higher the impact of mood in decision making. A positive mood state can make investors more optimistic and willing to undertake riskier investment decisions (Wright \& Bower, 1992). The proxy variables that have been used in the relevant studies in order to gauge social mood include weather (Saunders, 1993), biorhythms (Kamstra et al., 2003) and beliefs relating to Lunar phases or Friday $13^{\text {th }}$ (Dowling \& Lucey, 2005).

With respect to the role of religion in affecting investor mood and behavior, Pantzalis \& Ucar (2014) examined the impact of the Easter week holiday on investors' behavior in the U.S. This religious practice is found to cause investors distraction which may lead to delayed reaction to firm news. Frieder \& Subrahmanyam (2004) examined the impact of the Jewish High Holy Days (i.e., Rosh HaShanah and Yom Kippur) on U.S. stock returns and dollar volume. During both Holy days there is a significant decline in dollar volume, while stock

\footnotetext{
${ }^{1}$ Loewenstein et al. (2001); Lucey \& Dowling (2005); Nofsinger (2005), Shu (2010), Summers \& Duxbury (2012), Abu Bakar et al. (2014) and Siganos et al. (2014).
} 
returns are significantly positive around Rosh HaShanah and significantly negative around Yom Kippur. ${ }^{2}$ Frieder \& Subrahmanyam (2004) attribute these phenomena to Jewish investor sentiment. ${ }^{3}$ In addition, the positive mood effects of Ramadan on investor behavior have been identified in a series of studies which examined stock returns in Muslim countries (AlHajieh et al., 2011; Białkowski et al., 2012; Al-Khazali, 2014). In general, these studies suggest that stock returns are significantly higher during Ramadan than non-Ramadan days.

Motivated by this evidence, the fact that Ramadan has been shown to be associated with overall positive mood, expressed through optimism and enhanced social interactions, and the well documented relation of social mood with herding (e.g., Prechter 2001; Parker \& Prechter, 2005; Olson, 2006), the first question we consider in this study is whether herding exists in majority Muslim countries during the Ramadan-month. Additionally, if herding does exist, we ask whether its existence is more significant within Ramadan days compared to non-Ramadan days. More specifically, given that Ramadan is characterized by increased positive mood and social interaction (both of which are contributing factors to herding) among Muslims, we would expect that this would lead to an increase on the level of herd behavior during the Ramadan period. A third question is whether controlling for a variety of (domestic and international) market states produces an effect over the relationship between herding and Ramadan given the sensitivity of herding to market conditions (see e.g. Chang et al., 2000). It is these three questions that our study addresses.

Our findings reveal evidence of herding significance within-Ramadan for most (five out of seven) of our sample markets (Malaysia and Pakistan are the exceptions). Furthermore,

\footnotetext{
${ }^{2}$ The authors argue that days around Rosh HaShanah (the Jewish New Year) are associated with positive mood, overconfidence and under-estimation of risk, leading to higher stock market returns. On the contrary, Yom Kippur, as a day of regret, induces negative mood and subsequently lead to negative market returns.

${ }^{3}$ Even though Jews constitute a relatively low proportion of the U.S. population, their economic impact appears disproportionate to its size. The authors outline the Jewish community's importance on the U.S. financial community referring to the contribution of Jewish companies such as Goldman Sachs \& Co. and Salomon Brothers, among others, to investment banking. In addition, the authors refer to the higher income of Jews relative to other ethnic groups in the U.S. Based on the above arguments, the authors support their hypothesis that Jewish investors have a significant impact on the U.S. stock market.
} 
when herding is significant both within and outside Ramadan, its magnitude within-Ramadan is always higher than outside Ramadan. Overall, herding significance within/outside Ramadan exhibits some variation in its levels across markets in relation to variables that reflect domestic (market returns; market volume) or international (US market returns; US investors' sentiment; global financial crisis) market states.

These results make original contributions to the literature on the effects of social norms on markets (e.g., Hong et al., 2004; Hong et al., 2005; Hong \& Kacperczyk, 2009), herding (Prechter 2001; Parker \& Prechter, 2005; Olson, 2006) and Islamic finance in particular (AlHajieh et al., 2011; Białkowski et al., 2012; Al-Khazali, 2014). First, our findings are in line with social norm theory which argues that individuals follow the behavioral norms, beliefs and/or actions of other community members (Akerlof, 1980; Romer, 1984), with a focus on religious social norms. While previous Ramadan-related studies make inferences about the impact of Ramadan upon investors' behavior indirectly (by examining Ramadan as a seasonal anomaly), we test directly for the Ramadan-effect over a widely documented manifestation of investors' behavior, namely herding. As the first-ever study of the effect of religion over herding, our work contributes substantially to the wider literature on the role of religion in finance. ${ }^{4}$ Second, to the extent that social interactions and positive sentiment constitute Ramadan's two key behavioral features, our work at the aggregate market level confirms prior evidence from microdata-based research (Hong et al., 2004; Hong et al., 2005; Liao et al., 2011) on the relevance of these two features to the propensity to herd. Third, our study helps showcase Ramadan as a sentiment-proxy when researching majority Muslim markets in terms of herding and other behavioral phenomena. ${ }^{5}$

\footnotetext{
${ }^{4}$ See Glaeser \& Scheinkman (2003) for a discussion on the importance of social interactions (or peer effects) more generally for a variety of economic outcomes.

${ }^{5}$ The effect of sentiment has been depicted to date with regards to several behavioral patterns, including feedback trading (Chau et al., 2011) and momentum (Antoniou et al, 2013).
} 
From an Islamic finance viewpoint, useful implications arise for traders with exposure to equity markets of majority Muslim countries, as our results provide insight into investors' behavior during a month which entails abnormally high returns. For example, in recent years, there has been a surge of products either investing in Muslim countries or compliant with Shariah principles. ${ }^{6}$ Specifically, investors might take advantage of the abnormal returns during Ramadan. However, they should be cautious about the destabilizing potential of herding which may lead to an increase of systemic risk.

The remainder of the paper is organized as follows. Section 2 discusses the relevant literature on herding and mood and states our hypotheses. Section 3 presents the method and the data employed. Section 4 discusses the empirical findings and Section 5 concludes.

\section{Literature review}

\subsection{Herd behavior and mood}

Herding pertains to similarity in behavior following interactive observation of actions or actions-payoffs (Hirshleifer \& Teoh, 2003). In short, investors herd when they sideline their private signals, choosing to mimic their fellow investors instead (Hwang \& Salmon (2004). From a theoretical viewpoint, herding can be classified as intentional or spurious (Bikhchandani \& Sharma, 2000; Holmes et al., 2013; Gavriilidis et al., 2013).

An investor herds intentionally when his imitation is motivated by the anticipation of a benefit in an environment characterized by some sort of asymmetry. This is usually either informational or professional in nature. From an informational perspective, investors resort to herding when experiencing a state of (actual or perceived) informational disadvantage. For example, they may possess information of low quality or have inadequate informationprocessing skills compared to their peers (Devenow \& Welch, 1996). In the extreme, if many

\footnotetext{
${ }^{6}$ Shariah is an Islamic Jurisprudence.
} 
investors choose to follow the information of those they consider better informed, this can reduce the wealth of the public information pool and lead to cascading phenomena (Banerjee, 1992; Bikhchandani et al., 1992). Herding can also arise due to professional considerations, in particular among investment professionals, as a result of differences in their ability or reputation. Where fund managers are assessed periodically on a relative basis, low performing managers ("bad" managers) may consider mimicking the actions of their betterable peers ("good" managers) (Scharfstein \& Stein, 1990).

Investors herd spuriously when that action is the result of a common element in their environment. Examples include relative homogeneity (DeBondt \& Teh, 1997) and characteristic trading (Bennett, 2003). Relative homogeneity refers to similarities in the educational background, signals (e.g., ratios) received and their processing by investment professionals (Wermers, 1999). The regulatory environment can also induce herding, if its provisions limit the scope for investments. ${ }^{7}$ Characteristic trading (also known as style investing) refers to investments based on specific stock characteristics (e.g., past performance, price-to-earnings ratio, sector), thus leading to the employment of "investment styles" (e.g., momentum, value/growth).

A series of studies have demonstrated the importance of social interaction in general, and social mood in particular, as a driving force of herding. Olson (2006) suggests that emotions are prone to contagion among members in a group. Prechter (2001) suggests that fads and trends in financial markets are caused by emotions, which can lead investors to herd unconsciously. In addition, Parker \& Prechter (2005) show that, under conditions of uncertainty, unconscious herding impulses determine social mood, which in turn drives social actions, such as investing in the stock market. Hong et al., (2004) show how social interaction

\footnotetext{
${ }^{7}$ A typical example of this is documented in the pension funds of emerging markets, whose regulatory authorities constrain the opportunity set of stocks they can invest into by placing risk-profiling restrictions in equity-selection. For more on this see Olivares (2008) and Voronkova \& Bohl (2005).
} 
can foster herding among retail investors if it is used for observational learning purposes, ${ }^{8}$ while Hong et al., (2005) demonstrate that US fund managers located in the same city exhibit enhanced interaction which leads them to buy (sell) similar stocks. In relation to the role of sentiment in herding, Liao et al., (2011) find that US institutional investors tend to herd out of stocks that have previously exhibited over-optimistic sentiment, while Blasco et al., (2012) document the significant role of sentiment as an explanatory factor of herding using highfrequency data for the Spanish market.

\subsection{Herding and mood during Ramadan}

Several studies indicate that religion plays a significant role in the decisions of corporations and investors' risk-taking behavior (Hilary \& Hui, 2009; Białkowski et al., 2012). The Muslim holy month of Ramadan, in particular, has received notable attention. Celebrated by more than 1.5 billion Muslims across the world, Ramadan is a period during which Muslims abstain from eating, drinking, smoking or having other sensual pleasures from dawn till sunset. Clinical research finds that low levels of anxiety and increased levels of euphoria and social interactions are experienced during Ramadan (Daradkeh, 1992; Knerr \& Pearl, 2008).

To understand how Ramadan can promote herding tendencies among investors in majority Muslim countries, it is important to realize that it is a religious occasion that disciplines a person's life in specific ways (e.g., by defining a fasting timetable/prayer times, abstinence from sensual pleasures) for a relatively prolonged period of time (several weeks). ${ }^{9}$ The collective observation of Ramadan in these countries essentially suggests that its practice

\footnotetext{
${ }^{8}$ Investors may use these interactions to enhance their learning/understanding of equity investments (e.g., when discussing topics related to stock performance or stock-picking) and this can lead them to follow the choices of their fellow investors (e.g., an investor may choose to purchase stock A having recently heard that other investors trading that stock have realized profits from it).

${ }^{9}$ The temporal identification of Ramadan each year is based on the Islamic ("Hegirian") calendar which generates lunar years, incorporating 12 lunar months (each separated by a new moon and lasting 29 to 30 days) and lasts 354 days in total. The Ramadan-month is the ninth month in that calendar and because the lunar year is around 11 days shorter than the solar year (reflected through the Gregorian calendar), the location of Ramadan in the calendar falls around 11 days earlier from each successive solar year. For more, see Al-Khazali (2014).
} 
is mutually reinforcing among their Muslim population, leading them to demonstrate certain similarities in their day-to-day conduct. The joyful character of the specific occasion breeds enhanced levels of euphoria and spiritual uplifting (Knerr \& Pearl, 2008), which are further amplified via social interactions, which are of higher frequency during the Ramadan period (Białkowski et al., 2012). For those individual investors, the aforementioned psychological frame can lead to herding through the combination of two factors.

First, it tends to render people less risk-averse, leading them to choose investment options they would otherwise decline (Wright \& Bower, 1992; Nofsinger, 2002). Second, enhanced social interaction during Ramadan propagates such behaviour among investors. This is reinforced by the historically high returns during Ramadan, knowledge of which is likely to prompt investors to underestimate risk. As a result, Ramadan induces a state of interactively reinforced optimism and this can foment herding among investors, based on the definition of herding as imitative conduct following interactive observation of people's actions (Hirshleifer \& Teoh, 2003) and other research (Blasco et al, 2012) on the role of optimism in engineering herding in stock markets. Moreover, the common exposure of investors to this emotional state constitutes a factor inducing relative homogeneity of an emotional background in the market, suggesting that this herding is of spurious nature, in line with our earlier discussion on herding typology. Non-Ramadan days, in comparison, should be depicting lower herding levels, since this relatively homogeneous state of emotional elation in society is expected to diminish post-Ramadan.

These mood-effects of Ramadan have motivated several studies in finance, testing whether the enhanced social mood is transferred into the investment realm. Among the first studies on the impact of Ramadan on stock markets is that by Seyyed et al. (2005). Their examination of stock market behavior in Saudi Arabia for the period 1985-2000 shows no evidence of any difference in mean returns between Ramadan and non-Ramadan days. 
However, volatility in the Saudi Arabian stock market was lower during Ramadan. Using a sample of eight Middle Eastern countries for the period 1992-2007, Al-Hajieh et al. (2011) find positive abnormal returns during the month of Ramadan for the majority of countries examined. The authors attribute their findings to the positive investors' mood during Ramadan which is further reinforced by the enhanced social interaction characterizing its occasion. Białkowski et al. (2012) find that in a majority of 14 Muslim countries, stock returns during the month of Ramadan were higher than in non-Ramadan days. They attribute their findings to Ramadan promoting feelings of social identity and solidarity, hence increasing the optimism of investors and influencing their investment decisions accordingly. Finally, Al-Khazali (2014), using a sample of 15 Muslim countries for various time periods, confirm the presence of higher returns during Ramadan. However, the effect dissipated following the outbreak of the recent financial crisis.

Our empirical analysis aims to establish whether the positive mood documented during Ramadan translates into higher herding compared to non-Ramadan days, in view of the extant aforementioned evidence on the relationship between herding and social mood. In fact, the possibility of herding constituting an explanation underlying the Ramadan-effect has been put forward by Al-Khazali (2014) and Al-Hajieh et al. (2011). Although both studies argue that investors during Ramadan are exposed to common psychological stimuli which may lead to herding tendencies, no explicit tests are undertaken. We test the robustness of our findings against a series of domestic (market returns; market volume) or international (US market returns; US investors' sentiment; global financial crisis) market conditions. ${ }^{10}$ To this end, we

\footnotetext{
${ }^{10}$ The sensitivity of herding to different market conditions has been widely documented. Holmes et al. (2013) show that institutional investors' herding varies with market returns, market volatility and regulatory changes. Gavriilidis et al. (2013) show that, market conditions aside, the propensity of institutional investors to herd can also be affected by industry conditions. At the aggregate market level, Chang et al. (2000), Chiang and Zheng (2010) and Economou et al. (2011) produce evidence for the impact of different market states on the significance of herding.
} 
employ a sample of seven Muslim dominated countries: Bangladesh, Egypt, Indonesia, Malaysia, Morocco, Pakistan and Turkey. We address the following questions:

a) Does herding exist during the Ramadan-month?

b) Is herding higher during the Ramadan-month compared to non-Ramadan days?

c) Does the relationship between herding and Ramadan vary with different domestic/ international market states and the recent global financial crisis?

\section{Methodology and data}

\subsection{Methodology}

Our empirical design is based on the notion of herding proposed by Christie \& Huang (1995) and Chang et al. (2000), according to which, herding is reflected in a reduced securities' return-dispersion during periods of market stress. Whereas Christie \& Huang (1995) assumed the relationship between the cross sectional dispersion of stock returns and market returns to be linear, ${ }^{11}$ there exists ample evidence linking herding to nonlinear dynamics in capital markets. ${ }^{12}$ Chang et al. (2000) proposed a herding measure accounting for the possibility of nonlinearities in the relationship between the cross sectional dispersion of stock returns and market returns. It is their approach we follow here. More specifically, they use the following empirical specification:

$\operatorname{CSAD}_{\mathrm{t}}=\alpha_{0}+\alpha_{1}\left|\mathrm{r}_{\mathrm{m}, \mathrm{t}}\right|+\alpha_{2} \mathrm{r}_{\mathrm{m}, \mathrm{t}}^{2}+\varepsilon_{\mathrm{t}}$

where CSAD is the cross sectional absolute deviation of returns calculated as:

$$
C S A D_{t}=\frac{1}{n} \sum_{i=1}^{N}\left|r_{i, t}-r_{m, t}\right|
$$

\footnotetext{
${ }^{11}$ Christie \& Huang (1995) tested for herding by regressing the cross sectional returns' dispersion over two dummies, one for extreme-up and one for extreme-down market returns ("extreme" being identified in their paper with various areas of the tails of the market returns' distribution). Negative values of the dummies' coefficients would signify the presence of herding, as they would suggest a reduction in the returns' dispersion. ${ }^{12}$ E.g., Lux (1995), Iori (2002) and Focardi et al. (2002).
} 
where $\mathrm{r}_{\mathrm{i}, \mathrm{t}}$ is the return on security $i$ on day $t, \mathrm{r}_{\mathrm{m}, \mathrm{t}}$ is the market-average on day $t$ (calculated by averaging the returns of all securities for day $t$ ) and $n$ is the total number of securities traded on day $t$. According to Chang et al. (2000), under rational asset pricing, the dispersion of the returns would be linearly and positively related to the absolute returns of the market, given the fact that stocks differ in their sensitivities to changes in market returns. In the case of extreme market conditions, i.e. periods with high absolute values of market returns, this would lead to increased values of CSAD. However, if herding is present during such periods, stock returns would be expected to follow the return of the market. In other words, this would lead to a reduction in the values of CSAD. As such, herding would imply a negative relationship between CSAD and absolute market returns. During extreme periods, this relationship might lose its linearity, hence the inclusion of the squared market return term on the right hand side of the equation which would be translated into a significantly negative value of the $\alpha_{2}$-coefficient (indicative of a reduced dispersion of returns in the presence of nonlinearities).

To test whether herding is different during Ramadan-days as opposed to days outside Ramadan, we first construct a dummy variable (D) taking the value of one during Ramadandays and zero during non-Ramadan days and then identify Ramadan-days in each year following the procedure outlined in Al-Khazali (2014). We then employ the following specification for each market:

$\operatorname{CSAD}_{\mathrm{t}}=\alpha_{0}+\alpha_{1} \mathrm{D}\left|\mathrm{r}_{\mathrm{m}, \mathrm{t}}\right|+\alpha_{2}(1-\mathrm{D})\left|\mathrm{r}_{\mathrm{m}, \mathrm{t}}\right|+\alpha_{3} \mathrm{Dr}_{\mathrm{m}, \mathrm{t}}^{2}+\alpha_{4}(1-\mathrm{D}) \mathrm{r}_{\mathrm{m}, \mathrm{t}}^{2}+\varepsilon_{\mathrm{t}}$

Given the above discussion, significantly negative values for $\alpha_{3}\left(\alpha_{4}\right)$ would indicate the presence of significant herding during (outside) Ramadan-days.

Having run equation (3) for each of our sample markets, we then assess whether our results are robust to changes in variables pertaining to domestic and international market conditions: 
- Domestic market performance (i.e. whether herding exhibits differences between days of positive versus days of negative domestic market returns), ${ }^{13}$ proxied here through $\mathrm{r}_{\mathrm{m}, \mathrm{t}}$. In

this case, we run the following set of equations for each market:

$$
\begin{aligned}
& \mathrm{CSAD}_{\mathrm{t}}=\alpha_{0}+\alpha_{1}{ }^{\mathrm{UP}} \mathrm{D}\left|\mathrm{r}_{\mathrm{m}, \mathrm{t}}\right|+\alpha_{2}{ }^{\mathrm{UP}}(1-\mathrm{D})\left|\mathrm{r}_{\mathrm{m}, \mathrm{t}}\right|+\alpha_{3}{ }^{\mathrm{UP}} \mathrm{Dr}_{\mathrm{m}, \mathrm{t}}{ }^{2}+\alpha_{4}{ }^{\mathrm{UP}}(1-\mathrm{D}) \mathrm{r}_{\mathrm{m}, \mathrm{t}}{ }^{2}+\varepsilon_{\mathrm{t}} \\
& \mathrm{CSAD}_{\mathrm{t}}=\alpha_{0}+\alpha_{1}{ }^{\mathrm{DOWN}} \mathrm{D}\left|\mathrm{r}_{\mathrm{m}, \mathrm{t}}\right|+\alpha_{2}{ }^{\mathrm{DOWN}}(1-\mathrm{D})\left|\mathrm{r}_{\mathrm{m}, \mathrm{t}}\right|+\alpha_{3}{ }^{\mathrm{DOWN}} \mathrm{Dr}_{\mathrm{m}, \mathrm{t}}{ }^{2}+\alpha_{4}{ }^{\mathrm{DOWN}}(1-\mathrm{D}) \mathrm{r}_{\mathrm{m}, \mathrm{t}}{ }^{2}+\varepsilon_{\mathrm{t}}
\end{aligned}
$$

where the superscript UP (DOWN) denotes that the model is estimated for days of positive (negative) domestic market returns.

- Domestic market volume (i.e. whether herding differs between days of increased versus days of decreased domestic market volume), ${ }^{14}$ which we calculate daily by aggregating the volumes of all listed stocks in that market every day. In this case, we run the following set of equations for each market:

$$
\begin{aligned}
& \operatorname{CSAD}_{\mathrm{t}}=\alpha_{0}+\alpha_{1}{ }^{\mathrm{UPVol}} \mathrm{D}\left|\mathrm{r}_{\mathrm{m}, \mathrm{t}}\right|+\alpha_{2}{ }^{\mathrm{UPVol}}(1-\mathrm{D})\left|\mathrm{r}_{\mathrm{m}, \mathrm{t}}\right|+\alpha_{3}{ }^{\mathrm{UPVol}} \operatorname{Dr}_{\mathrm{m}, \mathrm{t}}^{2}+\alpha_{4}{ }^{\mathrm{UPVol}}(1-\mathrm{D}) \mathrm{r}_{\mathrm{m}, \mathrm{t}}^{2}+\varepsilon_{\mathrm{t}} \\
& \mathrm{CSAD}_{\mathrm{t}}=\alpha_{0}+\alpha_{1}{ }^{\text {DOWNVol}} \mathrm{D}\left|\mathrm{r}_{\mathrm{m}, \mathrm{t}}\right|+\alpha_{2}{ }^{\text {DOWNVol}}(1-\mathrm{D})\left|\mathrm{r}_{\mathrm{m}, \mathrm{t}}\right|+\alpha_{3}{ }^{\text {DOWNVol }} \operatorname{Dr}_{\mathrm{m}, \mathrm{t}}{ }^{2}+\alpha_{4}{ }^{\text {DOWNVol }}(1-\mathrm{D}) \mathrm{r}_{\mathrm{m}, \mathrm{t}}^{2}+\varepsilon_{\mathrm{t}}
\end{aligned}
$$

where the superscript UPVol (DOWNVol) denotes that the model is estimated for days of increasing (decreasing) domestic market volume.

- US market performance (i.e. whether our herding estimates are different when the US market exhibits positive versus negative returns), ${ }^{15}$ proxied here through the daily returns of the S\&P500 index. In this case, we run the following set of equations for each market:

$$
\mathrm{CSAD}_{\mathrm{t}}=\alpha_{0}+\alpha_{1}{ }^{\mathrm{UPUS}} \mathrm{D}\left|\mathrm{r}_{\mathrm{m}, \mathrm{t}}\right|+\alpha_{2}{ }^{\mathrm{UPUS}}(1-\mathrm{D})\left|\mathrm{r}_{\mathrm{m}, \mathrm{t}}\right|+\alpha_{3}{ }^{\mathrm{UPUS}} \mathrm{Dr}_{\mathrm{m}, \mathrm{t}}{ }^{2}+\alpha_{4}{ }^{\mathrm{UPUS}}(1-\mathrm{D}) \mathrm{r}_{\mathrm{m}, \mathrm{t}}^{2}+\varepsilon_{\mathrm{t}}
$$

\footnotetext{
${ }^{13}$ The effect of market performance upon herding has been demonstrated by a wealth of studies, including Chang et al. (2000), Chiang et al. (2010), Tan et al. (2008) and Economou et al. (2011). Down-markets tend to be conducive to herding, as they can lead investors to mimic their peers due to professional reasons (the case e.g. of "bad" fund managers copying the trades of their "good" peers; upon their performance assessment, "bad" managers in this case can always claim that they engaged in the right trades - those they copied from the "good" managers - and blame their poor performance on adverse market conditions) or risk-aversion (the choice of selling with the crowd early on to avoid selling at worse prices at a later stage should a slump persist). Upmarkets can also breed herding due to the generalized euphoria accompanying them. For more on how market returns can affect herding, see Holmes et al. (2013) and Gavriilidis et al. (2013).

${ }^{14}$ The effect of volume over herding has been denoted by several studies, including Tan et al. (2008) and Economou et al. (2011). High volume can boost herding in a market since it allows the entry of informed investors (whom uninformed traders can imitate) and reduces frictions due to thin trading (thus, rendering herding possible). For more discussion, see Gavriilidis et al. (2013).

${ }^{15}$ The role of the US market in investors' herding internationally has been depicted in Chiang \& Zheng (2010).
} 
$\mathrm{CSAD}_{\mathrm{t}}=\alpha_{0}+\alpha_{1}{ }^{\text {DOWNUS }} \mathrm{D}\left|\mathrm{r}_{\mathrm{m}, \mathrm{t}}\right|+\alpha_{2}{ }^{\text {DOWNUS }}(1-\mathrm{D})\left|\mathrm{r}_{\mathrm{m}, \mathrm{t}}\right|+\alpha_{3}{ }^{\text {DOWNUS }} \operatorname{Dr}_{\mathrm{m}, \mathrm{t}}^{2}+\alpha_{4}{ }^{\text {DOWNUS }}(1-\mathrm{D}) \mathrm{r}_{\mathrm{m}, \mathrm{t}}^{2}+\varepsilon_{\mathrm{t}}$

where the superscript UPUS (DOWNUS) denotes that the model is estimated for days of positive (negative) US market returns.

- US investors' sentiment (i.e. whether herding differs between days of improving versus days of deteriorating US investors' sentiment), proxied here through the CBOE VIX index. ${ }^{16}$ In this case, we run the following set of equations for each market:

$$
\begin{aligned}
& \mathrm{CSAD}_{\mathrm{t}}=\alpha_{0}+\alpha_{1}{ }^{\mathrm{UPVIX}} \mathrm{D}\left|\mathrm{r}_{\mathrm{m}, \mathrm{t}}\right|+\alpha_{2}{ }^{\mathrm{UPVIX}}(1-\mathrm{D})\left|\mathrm{r}_{\mathrm{m}, \mathrm{t}}\right|+\alpha_{3}{ }^{\mathrm{UPVIX}} \operatorname{Dr}_{\mathrm{m}, \mathrm{t}}^{2}+\alpha_{4}{ }^{\mathrm{UPVIX}}(1-\mathrm{D}) \mathrm{r}_{\mathrm{m}, \mathrm{t}}^{2}+\varepsilon_{\mathrm{t}}
\end{aligned}
$$

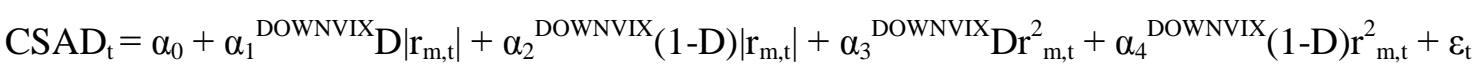

where the superscript UPVIX (DOWNVIX) denotes that the model is estimated for days of increasing/decreasing VIX-values.

Finally, we test whether controlling for the global financial crisis affects our results by rerunning equation (3) prior to and after the outbreak of the global financial crisis (i.e., September 2008). ${ }^{17}$ In this case, we run the following set of equations for each market:

$\operatorname{CSAD}_{\mathrm{t}}=\alpha_{0}+\alpha_{1}{ }^{\text {PREOUtBREAK }} \mathrm{D}\left|\mathrm{r}_{\mathrm{m}, \mathrm{t}}\right|+\alpha_{2}{ }^{\text {PREOUTBREAK }}(1-\mathrm{D})\left|\mathrm{r}_{\mathrm{m}, \mathrm{t}}\right|+\alpha_{3}{ }^{\text {PREOUTBREAK }} \mathrm{Dr}_{\mathrm{m}, \mathrm{t}}{ }^{2}+\alpha_{4}{ }^{\text {PREOUTBReAK }}(1-$

D) ${ }^{2}{ }_{m, t}+\varepsilon_{t}$

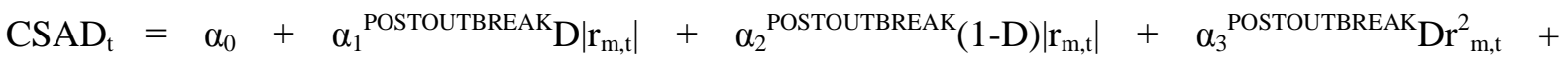
$\alpha_{4}{ }^{\text {POSTOUTBREAK }}(1-\mathrm{D}) \mathrm{r}_{\mathrm{m}, \mathrm{t}}^{2}+\varepsilon_{\mathrm{t}}$

where the superscript PREOUTBREAK (POSTOUTBREAK) denotes that the model is estimated prior to (after) the crisis' outbreak.

\subsection{Data}

Our data contain daily observations of the closing prices and trading volume from all ordinary stocks listed on the equity markets of Bangladesh, Egypt, Indonesia, Malaysia,

\footnotetext{
${ }^{16}$ The role of US investors' sentiment in global markets has been denoted by Verma \& Soydemir (2006). The CBOE VIX was introduced in 1993 and is an implied volatility index calculated based on S\&P500 options. According to Whaley (2000), the CBOE VIX is considered to gauge investors' fear. As such, higher levels of VIX would indicate higher uncertainty in the market. The relationship of the CBOE VIX and herding has been widely documented in the herding literature (Chiang et al., 2013; Philippas et al., 2013).

${ }^{17}$ For more on the 2008 financial crisis see Ivashina \& Scharfstein (2010).
} 
Morocco, Pakistan and Turkey. All seven markets operate in majority Muslim countries for which data is available since the early 1990s. This allows us a time-window long enough to test for the relationship between herding and Ramadan. The start date of data for each market can, therefore, be traced in the 1990-1994 period, while the end-date is 28/2/2014 (see Table 1 for more details). To mitigate the possibility of survivorship bias affecting our results, our sample includes both active as well as dead/suspended stocks (for the period these were traded). In total, the number of stocks respectively is 366 for Bangladesh, 710 for Egypt, 588 for Indonesia, 1,296 for Malaysia, 108 for Morocco, 506 for Pakistan and 476 for Turkey. We also use data on the daily time series of the S\&P500 index and the CBOE VIX index. All data employed in this study were obtained from the Thomson-Reuters DataStream database.

Panel A in Table 1 presents descriptive statistics on the cross sectional absolute deviations (CSAD) of returns for all seven markets. Morocco's CSAD has the smallest mean value (0.0099), while Turkey's bears the highest $(0.0235)$, followed by Indonesia $(0.0224)$ and Pakistan (0.0207). Panel B presents the average daily trading volume for all seven markets. Seyyed et al. (2005) show that the trading volume in Saudi Arabia decreases during Ramadan. However, Al-Hajieh et al. (2011), using a sample of eight Muslim countries, finds no consistent impact of Ramadan on trading volumes. In some years, these appear increasing and in other years decreasing. For our sample, the trading volumes in six out of the seven sample countries decrease during Ramadan days (with the difference being significant at the 5\% level in all cases but Morocco, where the difference is significant at the $10 \%$ level). For Turkey, the trading volume is higher during Ramadan, although the difference is insignificant.

[TABLE 1 ABOUT HERE] 


\section{Results-Discussion}

\subsection{Empirical findings}

We begin our discussion with the results from equation (3). Using Newey-West consistent estimators, we first run a pooled OLS regression to present an overall picture of the impact of Ramadan on herding. ${ }^{18}$ The results presented in Table 2 (Panel A) reveal that, overall, herding is present during the Ramadan-month and stronger during Ramadan days $\left(\alpha_{3}\right.$ is negative and statistically significant and significantly higher than $\alpha_{4}$, in absolute terms). We split the sample to gauge whether the results in the first column are robust when conditioning herding upon a variety of market states pertaining to each of our sample markets individually and the US. We address the third research question by running equations 4 to 13 and we find the following. Herding is present only within the Ramadan period during domestic downmarket days, domestic down-volume days, US up-market days and during the pre-crisis period. Where herding is present both in Ramadan and non-Ramadan days, this appears stronger on Ramadan days during domestic up-market days, domestic up-volume days and US down-market days (with the difference being significant in all tests except during upmarket days). Herding is only present or appears stronger within non-Ramadan days during up-VIX days and during the post-crisis period.

We employ a country fixed-effect panel approach to account for time-invariant heterogeneity across our sample countries (Panel B). Our findings confirm the hypothesis that herding tendencies are amplified during Ramadan (with the difference being highly significant). In addition, herding is only present within the Ramadan period during domestic down-market days, domestic down-volume days, US up-market days and during the precrisis period. When herding appears during both periods, this appears stronger on Ramadan days during up-market days and up-volume days (with the difference being significant).

\footnotetext{
${ }^{18}$ We thank an anonymous reviewer for suggesting this approach.
} 
Finally, herding is only present or appears stronger within non-Ramadan days during up-VIX days and the post crisis period. Overall, in respect of our first two research questions, the evidence suggests that the common mood effects associated with Ramadan are associated with strong herding tendencies during Ramadan-days. ${ }^{19}$

\section{[TABLE 2 ABOUT HERE]}

We now present the results from equation (3) at a country level. The results reported in Table 3 indicate the presence of herding within Ramadan (reflected through significantly negative $\alpha_{3}$ values) in Bangladesh, Egypt, Indonesia, Morocco and Turkey. In Egypt, Indonesia and Turkey, herding is also significant outside Ramadan days $\left(\alpha_{4}\right.$ is significantly negative for them). For these three markets, we observe that in absolute terms $\alpha_{3}$ is always larger than $\alpha_{4}$, which suggests that herding in these markets is stronger within-Ramadan, although the difference between the estimates of $\alpha_{3}$ and $\alpha_{4}$ is significant for Turkey only. The markets in Malaysia and Pakistan exhibit significant herding only outside Ramadan days.

\section{[TABLE 3 ABOUT HERE]}

Table 4 presents the estimates from equations (4) and (5) where we control for the impact of the domestic market's returns over the relationship between herding and Ramadan at a country level. The results are in line with those outlined in the previous table. Significant herding is detected within Ramadan in Bangladesh (during down-market days), Indonesia, Morocco and Turkey (during both up- and down-market days), while no herding is detected in Egypt within Ramadan. With the exception of Morocco, herding is significant outside Ramadan days in the rest of the markets, either only during up-market (Indonesia and

\footnotetext{
${ }^{19}$ The country variations in herd behaviour could be due to the differences in the level of religiosity among the sample countries. To test for this hypothesis, we rerun our regressions by adding a control variable for the ratio of Muslim population to total population. The fraction of Muslim population has been obtained from the Central Intelligence Agency (CIA) World Factbook (2013), as in Biakowski et al (2012). These unreported results are quantitatively similar and are available upon request. We thank the guest editors for this comment.
} 
Turkey) or down-market (Bangladesh) days or during both (Egypt, Malaysia and Pakistan). For those tests where herding is significant both within and outside Ramadan days (Bangladesh for down-market days; Indonesia and Turkey for up-market days), herding appears stronger within Ramadan (the value in absolute terms of $\alpha_{3}$ is always larger than that of $\alpha_{4}$ ), with the difference between the estimates of $\alpha_{3}$ and $\alpha_{4}$ being significant for Indonesia only.

Overall, the significance of herding in Ramadan is not affected by market performance in Indonesia, Morocco and Turkey, while it manifests itself only during down-market days in Bangladesh. An interesting observation in this respect is that for those markets (Indonesia, Morocco and Turkey) where herding is detected within Ramadan during both up- and downmarket days, the values of $\alpha_{3}$ are larger in absolute terms during up- compared to downmarket days. This suggests that, although herding during Ramadan is present irrespective of the market's performance, it appears stronger during days of positive market performance within Ramadan. A possible explanation for this is that herding during a period of overall positive mood like Ramadan's appears the strongest during days when the market is reflective of this mood (i.e., up-market days). These results indicate a link between herding and overall positive market returns during Ramadan and are largely in line with prior evidence (Al-Hajieh et al., 2011; Białkowski et al., 2012; Al-Khazali, 2014) indirectly attributing Ramadan's highly positive returns to commonalities in investors' positive mood during Ramadan in majority Muslim countries. ${ }^{20}$

\section{[TABLE 4 ABOUT HERE]}

Table 5 presents the results from equations (6) and (7), where herding is conditioned upon the domestic market's volume rising or falling day-to-day. Significant herding is reported within-

\footnotetext{
${ }^{20}$ It is noted here that Indonesia, Morocco and Turkey are the three markets in our sample with the highest average in-Ramadan market returns $(6.1 \%, 10.1 \%$ and $4.7 \%$, respectively).
} 
Ramadan during both increasing and decreasing volume days for Bangladesh, Indonesia, Morocco and Turkey. Bangladesh and Indonesia indicate significant herding outside Ramadan days during increasing volume days, Turkey during decreasing volume days, while no evidence of significant herding is presented for Morocco outside Ramadan. Where herding is significant both within and outside Ramadan days (Bangladesh and Indonesia for increasing volume days; Turkey for decreasing volume days), herding appears stronger within Ramadan ( $\alpha_{3}$ in absolute terms is always greater in value than $\alpha_{4}$ ), with the difference between $\alpha_{3}$ and $\alpha_{4}$ being significant in all cases. For the remaining three markets are concerned, herding is only significant during non Ramadan days: both for increasing and decreasing volume days in Egypt and Pakistan and increasing volume days in Malaysia. ${ }^{21}$ In three of the four markets where herding in Ramadan is present during both increasing and decreasing volume days (Bangladesh, Indonesia and Morocco, with the exception of Turkey), the absolute values of $\alpha_{3}$ are larger during increasing compared to decreasing volume days. This suggests that, although herding is present during the Ramadan period irrespective of trading volumes, it appears stronger during days of increasing market volume within Ramadan. A possibility here is that herding grows stronger in Ramadan during days with increased market volume, as the latter helps reduce frictions in trading, thus rendering herding feasible, by allowing those willing to herd the opportunity to do so (Gavriilidis et al., 2013).

\section{[TABLE 5 ABOUT HERE]}

Conditioning herding estimations upon the daily movements of the US market (indicated by the S\&P500 index), we report evidence of herding within Ramadan for almost all markets

\footnotetext{
${ }^{21}$ In line with Economou et al. (2011), we have repeated these tests controlling for the effect of domestic market volume using the 30-day moving average of volume (i.e., whether volume is greater than or less than its 30-day moving average). The results of these tests are very similar to those reported here and are available upon request.
} 
(bar Pakistan, where herding is significant outside Ramadan days only). Table 6 shows this to be the case during up- and down-market days for Bangladesh, Morocco and Turkey, downmarket days for Egypt and Malaysia and up-market days for Indonesia. ${ }^{22}$ With the exception of Morocco, the remaining markets exhibit widespread evidence of herding during nonRamadan days as well. This is the case during up- and down-market days for Egypt and Malaysia, up-market days for Turkey and down-market days for Bangladesh and Indonesia. For tests where herding is significant both within and outside Ramadan days (down-market days for Bangladesh, Egypt and Malaysia; up-market days for Turkey), the absolute value of $\alpha_{3}$ is always larger than that of $\alpha_{4}$. For those cases, herding is more intense within Ramadan, with the difference between the estimates of $\alpha_{3}$ and $\alpha_{4}$ being significant in all cases. For those markets where herding is significant during both up- and down-markets in Ramadan, our evidence on the relationship between herding and US market returns in Ramadan is mixed, with absolute values of $\alpha_{3}$ being larger during down- (up-) market days in Bangladesh and Morocco (Turkey).

\section{[TABLE 6 ABOUT HERE]}

Table 7 presents the results from equations (10) and (11) where we condition herding upon daily changes of the US investors' sentiment index (VIX). Significant herding exists within Ramadan during increasing and decreasing days for the VIX in Indonesia, Morocco and Turkey and increasing VIX-days only in Bangladesh, Egypt and Malaysia. For Pakistan, there is significant herding only outside Ramadan days. Herding outside Ramadan is indicated during increasing VIX-days in Bangladesh and Indonesia, decreasing VIX-days in Turkey and increasing/decreasing VIX-days in Egypt and Malaysia. Any test for which herding is significant both within Ramadan and outside Ramadan days entails absolute

\footnotetext{
${ }^{22}$ The up-/down-market days mentioned here refer to the US market and should not be confused with the up/down-market days when we discuss the results in Table 4 (which referred to each of our sample markets).
} 
values of $\alpha_{3}$ exceeding in absolute terms the corresponding $\alpha_{4}$ values, with the difference being significant in all tests. These results confirm the stronger presence of herding during Ramadan days.

From the estimates presented in Table 7, herding in Ramadan is significant during upVIX days (six markets) compared to down-VIX ones (three markets). This is confirmed when looking at those markets for which herding in Ramadan is significant during both up- and down-VIX days (Indonesia; Morocco; Turkey). The absolute $\alpha_{3}$-values for Indonesia and Morocco are larger during up- compared to down-VIX days (indicating that herding in these two markets is stronger in Ramadan during days when the VIX has appreciated in value), with the reverse being the case for Turkey. Given that an increase in VIX is associated with a rise in "fear" among investors in the US (it predicts higher volatility during the next 30 days), our findings indicate that herding in Ramadan in our sample markets is related to rising VIXvalues. The latter is reported for the first time in the literature and is in line with extant research (Chiang et al., 2013; Philippas et al., 2013) demonstrating the role of increasing VIX values in motivating herding internationally.

\section{[TABLE 7 ABOUT HERE]}

In order to control for the effect of the global financial crisis that began in September 2008, we estimate equations (12) and (13) and present the corresponding results in Table 8. Significant herding within Ramadan is indicated in Bangladesh and Indonesia both pre and post- 2008 and in Morocco and Turkey pre- 2008. In these markets, herding is significant during non Ramadan days pre and post- 2008 in Indonesia and Turkey and post-2008 in Bangladesh. The other three markets (Egypt, Malaysia and Pakistan) show evidence of herding significance only outside Ramadan days, irrespective of period. Where herding is significant within and outside Ramadan, the absolute values of $\alpha_{3}$ are larger than those of $\alpha_{4}$ 
(with the difference being statistically significant in Indonesia post-2008 and Turkey pre2008), confirming that herding is more pronounced during Ramadan days.

The outbreak of the 2008 crisis affected investment patterns generally across world markets. It is possible that this has affected the propensity of investors in majority Muslim countries to herd during Ramadan. The reduction of the Ramadan effect in herding post-2008 is interesting, more so in view of evidence from Al-Khazali (2014) showing that the Ramadan effect in stock returns also scaled back substantially in majority Muslim markets after $2008 .^{23}$

\section{[TABLE 8 ABOUT HERE]}

\subsection{Discussion - contributions}

The results outlined in Tables 2-8 generally demonstrate that herding is present during Ramadan. In most of our sample markets, herding appears significantly stronger within rather than outside Ramadan (for most cases whereby it is significant on both Ramadan and non Ramadan days). These findings are reported for the first time in the literature. Thus, we contribute to the herding as well as Islamic finance literature in the following ways.

Unlike most studies that examine Ramadan from a market efficiency viewpoint (i.e. as a seasonal anomaly; see the review by Al-Khazali, 2014) our work takes a behavioral perspective, thereby addressing a literature gap in the wider debate over the role of religion in

\footnotetext{
${ }^{23}$ To account for the possibility that the time-difference between the sample countries and the US affects our estimates from the tests controlling for US variables (S\&P500/VIX), we repeated all tests controlling for these variables, this time conditioning herding upon their lagged values. Results overall confirm the patterns reported in Tables 6 and 7. We also tested for the possibility of the size-effect in our findings by performing all tests using value-weighted CSADs; results from these tests confirmed overall the findings presented in Tables 2-8. Finally, in order to test for the impact of the political instability in Egypt in 2011, we rerun the regressions from equations (3) to (9) for the Egyptian market (we thank the guest editors for this comment). These are qualitatively similar to those reported here. Results for all the above tests are not reported here in the interest of brevity and are available upon request.
} 
investors' behavior. ${ }^{24}$ To the extent that Ramadan is associated with specific behavioral facets - in particular enhanced social interactions and optimism (Białkowski et al., 2012) - our results are in line with research on the role of social interactions (Hong et al., 2004; Hong et al., 2005) and positive sentiment (Liao et al., 2011) over the propensity to herd. Given that this research has been undertaken mainly within a micro context (i.e., based on data from individual - retail as well as institutional - market participants' trades and accounts), the evidence presented in this study offers new insight on these issues from an aggregate market perspective. ${ }^{25}$ By showing the relationship between herding and a sentiment-related occasion like Ramadan, our study demonstrates that Ramadan should be considered as a sentimentproxy when researching herding (as well as other sentiment-related behavioral phenomena, such as feedback trading and momentum) in majority Muslim markets.

Herding significance within/outside Ramadan exhibits some variation in its robustness across markets to different market states, whether domestic (market returns; market volume) or international (US market returns; US investors' sentiment; global financial crisis). The significance of herding within Ramadan appears more consistent in Bangladesh, Indonesia, Morocco and Turkey compared to Egypt. ${ }^{26}$ Herding outside Ramadan is consistently significant in some markets (Egypt; Malaysia; Pakistan) and less so in others (Indonesia;

\footnotetext{
${ }^{24}$ The effect of Ramadan over investors' behavior has been rather scantly investigated to date. A study relevant to this issue is the one by Białkowski et al. (2013) which links mutual funds' performance in Turkey with the Ramadan-effect.

${ }^{25}$ Our study is based on aggregate market data (i.e. equity prices), whereas the studies mentioned here assess investors' behavior using transaction data.

${ }^{26}$ We refer specifically to those five markets, because they are the ones with significant herding withinRamadan in the unconditional herding test of equation (3). There are very few exceptions to the observed herding significance within-Ramadan in Bangladesh (domestic up-market days; down-VIX days), Indonesia (US up-market days), Morocco (post-crisis' outbreak) and Turkey (post-crisis' outbreak); conversely, the significance of herding within-Ramadan in Egypt is only observed during US down-market days and up-VIX days.
} 
Turkey). ${ }^{27}$ This highlights the versatility of the relationship between herding and Ramadan, while lending support to research showcasing the sensitivity of herding to market conditions (Chang et al., 2000; Chiang \& Zheng, 2010; Holmes et al., 2013). Given their emerging market status, the fact that all seven markets exhibit widespread evidence of herding (within and/or outside Ramadan) is in line with findings (e.g. Chang et al., 2000) that market participants are more susceptible to herding in emerging stock exchanges.

\section{Conclusion}

This paper examines the relationship between herding and Ramadan motivated by emotional/behavioral expressions (enhanced social interactions; optimism) which have been observed to facilitate herding and particularly during Ramadan. Drawing on a sample of seven stock markets from majority Muslim countries, we document the presence of significant herding during Ramadan in most of our sample markets. We also show that herding appears significantly stronger within Ramadan for most tests where it is significant on both Ramadan and non Ramadan days. Overall, herding significance within/outside Ramadan exhibits some variation in its robustness across markets to variables reflective of domestic (market returns; market volume) or international (US market returns; US investors' sentiment; global financial crisis) market states.

\footnotetext{
${ }^{27}$ We refer specifically to those five markets, because they are the ones with significant herding outsideRamadan in the unconditional herding test of equation (3). Herding outside-Ramadan is insignificant only during decreasing domestic volume days in Malaysia; conversely, the significance of herding outside-Ramadan is not observed on several occasions in Indonesia (domestic down-market days; decreasing domestic volume days; US up-market days; down-VIX days) and Turkey (domestic down-market days; increasing domestic volume days; US down-market days; up-VIX days). It is perhaps worth noting that the two markets (Malaysia and Pakistan) for which no evidence of herding was identified during Ramadan are those whose in-Ramadan average market returns are lower compared to outside-Ramadan average market returns; the $r_{m, t}$ of the Chang et al. (2000) model was used as a proxy of average market returns. The in- (outside-) Ramadan average market returns are as follows: Bangladesh: 4.2\% (3.2\%); Egypt: 4.6\% (1.9\%); Indonesia: $6.1 \%$ (5.6\%); Malaysia: $-2.3 \%$ (0.3\%); Morocco: $10.1 \%$ (4.2\%); Pakistan: $4.5 \%$ (4.7\%); Turkey: 4.7\% (2\%). Given the extant evidence mentioned earlier in this study of Ramadan being linked to highly positive returns compared to the rest of the year's days in majority Muslim countries, it is possible that the absence of herding in-Ramadan for these two countries may be the result of them bearing lower average returns in-Ramadan compared to non-Ramadan days.
} 
Our work produces original contributions on the impact of religion in financial decisions, by demonstrating that a religious occasion (Ramadan) is a determinant of herding significance. Previous research has only indirectly made inferences about the impact of Ramadan on investor behavior (by examining Ramadan as a seasonal anomaly). To the extent that social interactions and positive sentiment constitute Ramadan's two key behavioral features, our results confirm at the aggregate market level prior evidence from micro-level research on the effect of these two features upon herding. The role of Ramadan, as a sentiment-related occasion in motivating herding suggests that Ramadan constitutes a sentiment-proxy worth considering when researching herding in majority Muslim markets. This also contributes to the wider herding debate and the impact of social norms on markets by laying the ground for further research into whether major religious occasions (e.g., Catholic or Orthodox Easter week) can affect herding behavior. From the perspective of practitioners, our study contains implications for the investment community, in particular for traders with exposure to equity markets in majority Muslim countries. 


\section{REFERENCES:}

Abu Bakar, A., Siganos, A. \& Vagenas-Nanos, E., 2014. Does mood explain the Monday effect? Journal of Forecasting, 33(6), pp. 409-418.

Akerlof, G., 1980. A theory of social custom, of which unemployment may be one consequence. Quarterly Journal of Economics, 94, 749-775.

Al-Hajieh, H., Redhead, K. \& Rodgers, T., 2011. Investor sentiment and calendar anomaly effects: A case study of the impact of Ramadan on Islamic Middle Eastern markets. Research in International Business and Finance, 25(3), pp.345-356.

Al-Khazali, O., 2014. Revisiting fast profit investor sentiment and stock returns during Ramadan. International Review of Financial Analysis, (33), pp.157-170.

Antoniou, C., Doukas J. A. \& Subrahmanyam, A., 2013. Cognitive dissonance, sentiment and momentum. Journal of Financial and Quantitative Analysis, 48, pp. 245-275.

Banerjee, A. V., 1992. A Simple Model of Herd Behavior. The Quarterly Journal of Economics, 107(3), pp.797-817.

Barro, R.J. \& Mccleary, R., 2003. Religion and Economic Growth. NBER Working Paper No. 9682. Available at http://www.nber.org/papers/w9682.

Barsky, R.B, Juster, F.T, Kimball, M.S. \& Shapiro, M.D., 1997. Preference Parameters and Behavioral Heterogeneity. Quarterly Journal of Economics, 112 (2), pp.507-536.

Bennett, J.A., 2003. Greener Pastures and the Impact of Dynamic Institutional Preferences. Review of Financial Studies, 16(4), pp.1203-1238.

Białkowski, J. et al., 2013. Do mutual fund managers exploit the Ramadan anomaly? Evidence from Turkey. Emerging Markets Review, 15(C), pp.211-232.

Białkowski, J., Etebari, A. \& Wisniewski, T.P., 2012. Fast profits: Investor sentiment and stock returns during Ramadan. Journal of Banking \& Finance, 36(3), pp.835-845.

Bikhchandani, S., Hirshleifer, D. \& Welch, I., 1992. A Theory of Fads, Fashion, Custom, and Cultural Change in Informational Cascades. Journal of Political Economy, 100(5), pp.992-1026.

Bikhchandani, S. \& Sharma, S., 2000. Herd Behavior in Financial Markets: A Review, IMF Working Paper No. 00/48. Available at SSRN: http://ssrn.com/abstract=228343.

Blasco, N., Corredor, P. \& Ferreruela, S., 2012. Market sentiment: a key factor of investors' imitative behaviour. Accounting \& Finance, 52(3), pp.663-689.

Chang, E.C., Cheng, J.W. \& Khorana, A., 2000. An examination of herd behavior in equity markets: An international perspective. Journal of Banking \& Finance, 24(10), pp.1651-1679.

Chau, F., Deesomsak, R. \& Lau, M., 2011. Investor sentiment and feedback trading: evidence from the exchange traded funds market. International Review of Financial Analysis, 20, pp. 292-305.

Chiang, T. \& Zheng, D., 2010. An empirical analysis of herd behavior in global stock markets. Journal of Banking \& Finance, 34(8), pp.1911-1921.

Chiang, T.C., Li, J. \& Tan, L., 2010. Empirical investigation of herding behavior in Chinese stock markets: Evidence from quantile regression analysis. Global Finance Journal, 21(1), pp.111124.

Chiang, T., Tan, L., Li, J. \& Nelling, E., 2013. Dynamic herding behavior in Pacific-Basin markets: evidence and implications. Multinational Finance Journal, 17, pp.165-200.

Christie, W. \& Huang, R., 1995. Following the pied piper: Do individual returns herd around the market? Financial Analysts Journal, 51(4), pp.31-37.

Daradkeh, T., 1992. Parasuicide during Ramadan in Jordan. Acta Psychiatrica Scandinavica, 86(3), pp.253-254.

DeBondt, W.F.M \& Teh, L.L., 1997. Herding Behavior and Stock Returns: An Exploratory Investigation. Swiss Journal of Economics and Statistics (SJES), 133(II), pp.293-324.

Devenow, A. \& Welch, I., 1996. Rational herding in financial economics. European Economic Review, 40(3-5), pp.603-615.

Dowling, M. \& Lucey, B., 2005. Weather, biorhythms, beliefs and stock returns-Some preliminary Irish evidence. International Review of Financial Analysis, 14(3), pp.337-355.

Economou, F., Kostakis, A. \& Philippas, N., 2011. Cross-country effects in herding behaviour: Evidence from four south European markets. Journal of International Financial Markets, Institutions and Money, 21(3), pp.443-460. 
Focardi, S., Cincotti, S. \& Marchesi, M., 2002. Self-organization and market crashes. Journal of Economic Behavior \& Organization, 49(2), pp.241-267.

Frieder, L. \& Subrahmanyam, A., 2004. Nonsecular regularities in returns and volume. Financial Analysts Journal, 60(4), pp.29-34.

Gavriilidis, K., Kallinterakis, V. \& Ferreira, M.P.L., 2013. Institutional industry herding: Intentional or spurious? Journal of International Financial Markets, Institutions and Money, 26, pp.192214.

Glaeser, E., Scheinkman, J., 2003. Non-market interactions. In: Dewatripont, M., Hansen, L., Turnovsky, S. (Eds.), Advances in Economics and Econometrics: Theory and Applications, Eight World Congress. Cambridge University Press, Cambridge, pp. 339-370.

Guiso, L., Sapienza, P \& Zingales, L., 2003. People's Opium? Religion and Economic Attitudes. Journal of Monetary Economics, 50(1), pp.225-282.

Hilary, G. \& Hui, K.W., 2009. Does religion matter in corporate decision making in America? Journal of Financial Economics, 93(3), pp.455-473.

Hirshleifer, D. \& Hong Teoh, S., 2003. Herd Behaviour and Cascading in Capital Markets: a Review and Synthesis. European Financial Management, 9(1), pp.25-66.

Holmes, P., Kallinterakis, V. \& Ferreira, M.P.L., 2013. Herding in a Concentrated Market: a Question of Intent. European Financial Management, 19(3), pp.497-520.

Hong, H., \& Kacperczyk, M., 2009. The price of sin: The effects of social norms on markets Journal of Financial Economics, 93(1), pp.15-36.

Hong, H., Kubik, J.D. \& Stein, J.C., 2004. Social Interaction and Stock-Market Participation. The Journal of Finance, 59(1), pp.137-163.

Hong, H., Kubik, J.D. \& Stein, J.C., 2005. Thy Neighbor's Portfolio: Word-of-Mouth Effects in the Holdings and Trades of Money Managers. The Journal of Finance, 60(6), pp.2801-2824.

Hwang, S. \& Salmon, M., 2004. Market stress and herding. Journal of Empirical Finance, 11(4), pp.585-616.

Iori, G., 2002. A microsimulation of traders activity in the stock market: the role of heterogeneity, agents' interactions and trade frictions. Journal of Economic Behavior \& Organization, 49(2), pp.269-285.

Ivashina, V. \& Scharfstein, D., 2010. Bank lending during the financial crisis of 2008. Journal of Financial Economics, 97(3), pp.319-338.

Kamstra, M., Kramer, L. \& Levi, M., 2003. Winter blues: A SAD stock market cycle. American Economic Review, 93(1), pp.324-343.

Knerr, I. \& Pearl, P.L.P., 2008. Ketogenic diet: Stoking energy stores and still posing questions. Experimental Neurology, 211(1), pp.11-3.

Kumar, A., 2009. Who Gambles in the Stock Market? Journal of Finance, I.XIV (4), pp.1889-1933.

Kumar, A., Page, J.K. \& Spalt, O.G., 2011. Religious beliefs, gambling attitudes, and financial market outcomes. Journal of Financial Economics, 102, pp.671-708.

Liao, T.-L., Huang, C.-J. \& Wu, C.-Y., 2011. Do fund managers herd to counter investor sentiment? Journal of Business Research, 64(2), pp.207-212.

Loewenstein, G.F., Weber, E.U., Hsee, C.K. \& Welch, N., 2001. Risk as Feelings, Psychological Bulletin, 127(2), pp.267-286.

Lucey, B.M. \& Dowling, M., 2005. The Role of Feelings in Investor Decision-Making. Journal of Economic Surveys, 19(2), pp.211-237.

Lux, T., 1995. Herd behaviour, bubbles and crashes. Economic Journal, 105(431), pp.881-96.

Miller, A.S. \& Hoffmann, J.P., 1995. Risk and Religion: An Explanation of Gender Differences in Religiosity, Journal for the Scientific Study of Religion, 34 (1), pp.63-75.

Nofsinger, J.R., 2002. Do Optimists Make the Best Investors?. Corporate Finance Review 6(4), pp.11-17

Nofsinger, J., 2005. Social mood and financial economics. The Journal of Behavioral Finance, 6(3), pp.144-160.

Olivares, J.A., 2008. Rear-view-mirror driving in defined contribution systems: the strange formula of the Chilean pension funds. Applied Economics, 40(15), pp.2009-2019.

Olson, K.R., 2006. A Literature Review of Social Mood. The Journal of Behavioral Finance, 7(4), pp.193-203. 
Pantzalis, C. \& Ucar, E., 2014. Religious holidays, investor distraction, and earnings announcement effects. Journal of Banking \& Finance, (47), pp. 102-117.

Parker, W.D. \& Prechter, R.R., 2005. Herding: An Interdisciplinary Integrative Review from a Socionomic Perspective, Available at SSRN: http://ssrn.com/abstract=2009898

Philippas, N., Economou, F., Babalos, V. \& Kostakis, A., 2013. Herding Behavior in REITs: Novel tests and the role of financial crisis. International Review of Financial Analysis, 29, pp.166-174.

Prechter, R.R., 2001. Unconscious Herding Behavior as the Psychological Basis of Financial Market Trends and Patterns. Journal of Psychology and Financial Markets, 2(3), pp.120-125.

Renneboog, L. \& Spaenjers, C., 2012. Religion, economic attitudes, and household finance. Oxford Economic Papers, 64, pp.103-127.

Romer, D., 1984. The theory of social custom: a modification and some extensions. Quarterly Journal of Economics 99, 717-727.

Saunders, E.M.J., 1993. Stock Prices and Wall Street Weather. American Economic Review, 83(5), pp.1337-45.

Scharfstein, D.S. \& Stein, J.C., 1990. Herd Behavior and Investment. American Economic Review, 80(3), pp.465-79.

Seyyed, F., Abraham, A. \& Al-Hajji, M., 2005. Seasonality in stock returns and volatility: The Ramadan effect. Research in International Business and Finance, 19(3), pp.374-383.

Shu, H.-C., 2010. Investor mood and financial markets. Journal of Economic Behavior \& Organization, 76(2), pp.267-282.

Siganos, A., Vagenas-Nanos, E. \& Verwijmeren, P. 2014, Facebook's daily sentiment and international stock markets, Journal of Economic Behavior \& Organization, 107(B), pp.730743.

Stulz, R.M \& Williamson, R., 2003. Culture, openess, and finance. Journal of Financial Economics, 70 (3), pp.313-349.

Summers, B. \& Duxbury, D., 2012. Decision-dependent emotions and behavioral anomalies. Organizational Behavior and Human Decision Processes, 118(2), pp.226-238.

Tan, L. et al., 2008. Herding behavior in Chinese stock markets: An examination of A and B shares. Pacific-Basin Finance Journal, 16(1-2), pp.61-77.

Verma, R. \& Soydemir, G., 2006. The impact of US individual and institutional investor sentiment on foreign stock markets. The Journal of Behavioral Finance, 7(3), pp.128-144.

Voronkova, S. \& Bohl, M.T., 2005. Institutional Traders' Behavior in an Emerging Stock Market: Empirical Evidence on Polish Pension Fund Investors. Journal of Business Finance and Accounting, 32(7-8), pp.1537-1560.

Wermers, R., 1999. Mutual Fund Herding and the Impact on Stock Prices. The Journal of Finance, 54(2), pp.581-622.

Whaley, R.E., 2000. The investor fear gauge. Journal of Portfolio Management, 26, pp.12-17.

Wright, W. F. \& Bower, G. H., 1992. Mood Effects on Subjective Probability Assessment. Organizational Behavior and Human Decision Processes, 52, pp. 276-291. 
Table 1: Descriptive Statistics for CSAD and trading volume across all sample markets.

\begin{tabular}{|c|c|c|c|c|c|c|c|}
\hline \multicolumn{8}{|c|}{ Panel A. Descriptive statistics for CSAD } \\
\hline & Bangladesh & Egypt & Indonesia & Malaysia & Morocco & Pakistan & Turkey \\
\hline Start-date & $2 / 1 / 1992$ & $19 / 10 / 1994$ & $3 / 1 / 1990$ & $1 / 1 / 1990$ & $2 / 7 / 1993$ & $2 / 1 / 1991$ & $3 / 1 / 1990$ \\
\hline End-date & $28 / 2 / 2014$ & $28 / 2 / 2014$ & $28 / 2 / 2014$ & $28 / 2 / 2014$ & $28 / 2 / 2014$ & $28 / 2 / 2014$ & $28 / 2 / 2014$ \\
\hline Mean & 0,0171 & 0,0162 & 0,0224 & 0,0184 & 0,0099 & 0,0207 & 0,0235 \\
\hline Median & 0,0155 & 0,0157 & 0,0204 & 0,018 & 0,0098 & 0,0204 & 0,0203 \\
\hline Maximum & 0,6863 & 0,1331 & 0,6405 & 0,2577 & 0,1026 & 0,1758 & 0,2892 \\
\hline Minimum & 0,00002 & 0,000055 & 0,000026 & 0,000001 & 0,00013 & 0,000016 & 0,000002 \\
\hline $\begin{array}{l}\text { Standard } \\
\text { deviation }\end{array}$ & 0,0136 & 0,008 & 0,0168 & 0,0094 & 0,0062 & 0,0099 & 0,0124 \\
\hline $\begin{array}{l}\text { Number of } \\
\text { observations }\end{array}$ & 4782 & 4378 & 6088 & 6181 & 4985 & 5297 & 6010 \\
\hline \multicolumn{8}{|c|}{ Panel B. Average trading volume during non-Ramadan and Ramadan days. } \\
\hline & $\begin{array}{c}\text { Non- } \\
\text { Ramadan }\end{array}$ & Ramadan & \multicolumn{2}{|c|}{ Test of Difference } & & & \\
\hline Bangladesh & 53731,2 & 39786,0 & \multicolumn{2}{|c|}{$\begin{array}{c}4.67 \\
(0.0000)\end{array}$} & & & \\
\hline Egypt & 64681,0 & 47797,5 & \multicolumn{2}{|c|}{$\begin{array}{c}5.57 \\
(0.0000)\end{array}$} & & & \\
\hline Indonesia & 1851698,2 & 1602752,4 & \multicolumn{2}{|c|}{$\begin{array}{c}2.94 \\
(0.0033)\end{array}$} & & & \\
\hline Malaysia & 88609,5 & 80769,4 & \multicolumn{2}{|c|}{$\begin{array}{c}2.65 \\
(0.0000)\end{array}$} & & & \\
\hline Morocco & 2016,5 & 879,1 & \multicolumn{2}{|c|}{$\begin{array}{c}1.84 \\
(0.0654)\end{array}$} & & & \\
\hline Pakistan & 457782,6 & 357245,7 & \multicolumn{2}{|c|}{$\begin{array}{c}4.66 \\
(0.0000)\end{array}$} & & & \\
\hline Turkey & 532803,4 & 558150,8 & \multicolumn{2}{|c|}{$\begin{array}{c}-1.24 \\
(0.2141)\end{array}$} & & & \\
\hline
\end{tabular}

CSAD stands for cross sectional absolute deviation of returns. See section 3 for details on the method and sample selection. Trading volume is expressed in thousands of stocks. 
Table 2: Pooled OLS estimation and fixed effect panel estimation.

\begin{tabular}{|c|c|c|c|c|c|c|c|c|c|c|c|}
\hline & Overall & Up-market & Down-market & Up-volume & Down-volume & Up-S\&P500 & Down-S\&P500 & Up-Vix & Down-Vix & Pre-crisis & Post-crisis \\
\hline$\alpha_{0}$ & $\begin{array}{l}0.0141 \\
(0.0000)\end{array}$ & $\begin{array}{l}0.0150 \\
(0.0000)\end{array}$ & $\begin{array}{l}0.0150 \\
(0.0000)\end{array}$ & $\begin{array}{l}0.0144 \\
(0.0000)\end{array}$ & $\begin{array}{l}0.0142 \\
(0.0000)\end{array}$ & $\begin{array}{l}0.0141 \\
(0.0000)\end{array}$ & $\begin{array}{l}0.0139 \\
(0.0000)\end{array}$ & $\begin{array}{l}0.0139 \\
(0.0000)\end{array}$ & $\begin{array}{l}0.0143 \\
(0.0000)\end{array}$ & $\begin{array}{l}0.0132 \\
(0.0000)\end{array}$ & $\begin{array}{l}0.0137 \\
(0.0000)\end{array}$ \\
\hline$\alpha_{1}$ & $\begin{array}{l}0.4230 \\
(0.0000)\end{array}$ & $\begin{array}{l}0.3963 \\
(0.0000)\end{array}$ & $\begin{array}{l}0.3993 \\
(0.0000)\end{array}$ & $\begin{array}{l}0.3271 \\
(0.0000)\end{array}$ & $\begin{array}{l}0.4834 \\
(0.0000)\end{array}$ & $\begin{array}{l}0.4629 \\
(0.0000)\end{array}$ & $\begin{array}{l}0.5263 \\
(0.0000)\end{array}$ & $\begin{array}{l}0.3203 \\
(0.0000)\end{array}$ & $\begin{array}{l}0.3800 \\
(0.0000)\end{array}$ & $\begin{array}{l}0.2272 \\
(0.0000)\end{array}$ & $\begin{array}{l}0.4312 \\
(0.0000)\end{array}$ \\
\hline$\alpha_{2}$ & $\begin{array}{l}0.4058 \\
(0.0000)\end{array}$ & $\begin{array}{l}0.4017 \\
(0.0000)\end{array}$ & $\begin{array}{l}0.2897 \\
(0.0000)\end{array}$ & $\begin{array}{l}0.3888 \\
(0.0000)\end{array}$ & $\begin{array}{l}0.4137 \\
(0.0000)\end{array}$ & $\begin{array}{l}0.3917 \\
(0.0000)\end{array}$ & $\begin{array}{l}0.4640 \\
(0.0000)\end{array}$ & $\begin{array}{l}0.4612 \\
(0.0000)\end{array}$ & $\begin{array}{l}0.3887 \\
(0.0000)\end{array}$ & $\begin{array}{l}0.2842 \\
(0.0000)\end{array}$ & $\begin{array}{l}0.5938 \\
(0.0000)\end{array}$ \\
\hline$\alpha_{3}$ & $\begin{array}{r}-0.3117 \\
(0.0000)\end{array}$ & $\begin{array}{c}-0.2947 \\
(0.0000)\end{array}$ & $\begin{array}{c}-0.2924 \\
(0.0000)\end{array}$ & $\begin{array}{c}-0.6282 \\
(0.0000)\end{array}$ & $\begin{array}{c}-0.3536 \\
(0.0000)\end{array}$ & $\begin{array}{c}-0.3381 \\
(0.0000)\end{array}$ & $\begin{array}{c}-0.2604 \\
(0.0000)\end{array}$ & $\begin{array}{c}-0.2403 \\
(0.0000)\end{array}$ & $\begin{array}{l}0.6556 \\
(0.0000)\end{array}$ & $\begin{array}{c}-0.1714 \\
(0.0000)\end{array}$ & $\begin{array}{l}0.2101 \\
(0.0000)\end{array}$ \\
\hline$\alpha_{4}$ & $\begin{array}{r}-0.1177 \\
(0.0000)\end{array}$ & $\begin{array}{c}-0.2909 \\
(0.0000)\end{array}$ & $\begin{array}{l}0.8732 \\
(0.0000)\end{array}$ & $\begin{array}{c}-0.2454 \\
(0.0000)\end{array}$ & $\begin{array}{l}0.8182 \\
(0.0000)\end{array}$ & $\begin{array}{l}0.0313 \\
(0.0547)\end{array}$ & $\begin{array}{c}-0.0622 \\
(0.0000)\end{array}$ & $\begin{array}{c}-0.6694 \\
(0.0000)\end{array}$ & $\begin{array}{l}0.2057 \\
(0.0000)\end{array}$ & $\begin{array}{l}0.1348 \\
(0.0000)\end{array}$ & $\begin{array}{c}-0.1983 \\
(0.0075)\end{array}$ \\
\hline $\begin{array}{l}t \text {-stat1 } \\
\left(\mathrm{H}_{0}: \alpha_{1}=\alpha_{2}\right)\end{array}$ & $\begin{array}{c}2.62 \\
(0.1057)\end{array}$ & $\begin{array}{c}0.14 \\
(0.7131)\end{array}$ & $\begin{array}{c}56.31 \\
(0.0000)\end{array}$ & $\begin{array}{c}20.93 \\
(0.0000)\end{array}$ & $\begin{array}{c}22.92 \\
(0.0000)\end{array}$ & $\begin{array}{c}23.09 \\
(0.0000)\end{array}$ & $\begin{array}{c}6.68 \\
(0.0098)\end{array}$ & $\begin{array}{c}92.68 \\
(0.0000)\end{array}$ & $\begin{array}{c}0.20 \\
(0.6516)\end{array}$ & $\begin{array}{c}4.85 \\
(0.0277)\end{array}$ & $\begin{array}{c}13.02 \\
(0.0000)\end{array}$ \\
\hline $\begin{array}{l}t \text {-stat2 } \\
\left(\mathrm{H}_{0}: \alpha_{3}=\alpha_{4}\right)\end{array}$ & $\begin{array}{c}16.67 \\
(0.0000)\end{array}$ & $\begin{array}{c}0.04 \\
(0.8358)\end{array}$ & $\begin{array}{c}16.60 \\
(0.0000)\end{array}$ & $\begin{array}{c}45.84 \\
(0.0000)\end{array}$ & $\begin{array}{c}28.73 \\
(0.0000)\end{array}$ & $\begin{array}{l}35.75 \\
(0.0000)\end{array}$ & $\begin{array}{c}63.77 \\
(0.0000)\end{array}$ & $\begin{array}{c}37.15 \\
(0.0000)\end{array}$ & $\begin{array}{c}23.04 \\
(0.0000)\end{array}$ & $\begin{array}{c}14.53 \\
(0.0000)\end{array}$ & $\begin{array}{c}57.68 \\
(0.0000)\end{array}$ \\
\hline $\mathrm{R}^{2}$ & 0.2684 & 0.2335 & 0.3532 & 0.2307 & 0.4783 & 0.2932 & 0.2672 & 0.2641 & 0.3323 & 0.2652 & 0.3223 \\
\hline \multicolumn{12}{|c|}{ Panel B. Fixed effect panel estimation } \\
\hline & Overall & Up-market & Down-market & Up-volume & Down-volume & Up-S\&P500 & Down-S\&P500 & Up-Vix & Down-Vix & Pre-crisis & Post-crisis \\
\hline$\alpha_{0}$ & $\begin{array}{l}0.0182 \\
(0.0000)\end{array}$ & $\begin{array}{l}0.0188 \\
(0.0000)\end{array}$ & $\begin{array}{l}0.0195 \\
(0.0000)\end{array}$ & $\begin{array}{l}0.0189 \\
(0.0000)\end{array}$ & $\begin{array}{l}0.0179 \\
(0.0000)\end{array}$ & $\begin{array}{l}0.0183 \\
(0.0000)\end{array}$ & $\begin{array}{l}0.0177 \\
(0.0000)\end{array}$ & $\begin{array}{l}0.0181 \\
(0.0000)\end{array}$ & $\begin{array}{l}0.0180 \\
(0.0000)\end{array}$ & $\begin{array}{l}0.0188 \\
(0.0000)\end{array}$ & $\begin{array}{l}0.0174 \\
(0.0000)\end{array}$ \\
\hline$\alpha_{1}$ & $\begin{array}{l}0.3848 \\
(0.0000)\end{array}$ & $\begin{array}{l}0.3530 \\
(0.0000)\end{array}$ & $\begin{array}{l}0.3600 \\
(0.0000)\end{array}$ & $\begin{array}{l}0.2780 \\
(0.0000)\end{array}$ & $\begin{array}{l}0.4511 \\
(0.0000)\end{array}$ & $\begin{array}{l}0.4292 \\
(0.0000)\end{array}$ & $\begin{array}{l}0.4597 \\
(0.0000)\end{array}$ & $\begin{array}{l}0.2778 \\
(0.0000)\end{array}$ & $\begin{array}{l}0.3297 \\
(0.0000)\end{array}$ & $\begin{array}{l}0.3205 \\
(0.0000)\end{array}$ & $\begin{array}{l}0.3249 \\
(0.0000)\end{array}$ \\
\hline$\alpha_{2}$ & $\begin{array}{l}0.3602 \\
(0.0000)\end{array}$ & $\begin{array}{l}0.3497 \\
(0.0000)\end{array}$ & $\begin{array}{l}0.2409 \\
(0.0000)\end{array}$ & $\begin{array}{l}0.3372 \\
(0.0000)\end{array}$ & $\begin{array}{l}0.3713 \\
(0.0000)\end{array}$ & $\begin{array}{l}0.3465 \\
(0.0000)\end{array}$ & $\begin{array}{l}0.4178 \\
(0.0000)\end{array}$ & $\begin{array}{l}0.4134 \\
(0.0000)\end{array}$ & $\begin{array}{l}0.3447 \\
(0.0000)\end{array}$ & $\begin{array}{l}0.3651 \\
(0.0000)\end{array}$ & $\begin{array}{l}0.4685 \\
(0.0000)\end{array}$ \\
\hline$\alpha_{3}$ & $\begin{array}{c}-0.2858 \\
(0.0000)\end{array}$ & $\begin{array}{c}-0.2651 \\
(0.0000)\end{array}$ & $\begin{array}{c}-0.2659 \\
(0.0000)\end{array}$ & $\begin{array}{c}-0.5430 \\
(0.0000)\end{array}$ & $\begin{array}{c}-0.3321 \\
(0.0000)\end{array}$ & $\begin{array}{c}-0.3153 \\
(0.0000)\end{array}$ & $\begin{array}{c}-0.2276 \\
(0.0000)\end{array}$ & $\begin{array}{c}-0.2116 \\
(0.0000)\end{array}$ & $\begin{array}{l}0.8011 \\
(0.0000)\end{array}$ & $\begin{array}{c}-0.2418 \\
(0.0000)\end{array}$ & $\begin{array}{l}0.5571 \\
(0.0000)\end{array}$ \\
\hline$\alpha_{4}$ & $\begin{array}{c}-0.0413 \\
(0.0000)\end{array}$ & $\begin{array}{c}-0.2078 \\
(0.0000)\end{array}$ & $\begin{array}{l}0.9682 \\
(0.0000)\end{array}$ & $\begin{array}{c}-0.2119 \\
(0.0000)\end{array}$ & $\begin{array}{l}0.8902 \\
(0.0000)\end{array}$ & $\begin{array}{l}0.1039 \\
(0.0000)\end{array}$ & $\begin{array}{c}-0.0536 \\
(0.0000)\end{array}$ & $\begin{array}{c}-0.5853 \\
(0.0000)\end{array}$ & $\begin{array}{l}0.2760 \\
(0.0000)\end{array}$ & $\begin{array}{l}0.0001 \\
(0.0000)\end{array}$ & $\begin{array}{c}-0.1415 \\
(0.0000)\end{array}$ \\
\hline $\begin{array}{l}t \text {-stat1 } \\
\left(\mathrm{H}_{0}: \alpha_{1}=\alpha_{2}\right)\end{array}$ & $\begin{array}{c}5.90 \\
(0.0151)\end{array}$ & $\begin{array}{c}0.06 \\
(0.8093)\end{array}$ & $\begin{array}{c}75.21 \\
(0.0000)\end{array}$ & $\begin{array}{c}22.10 \\
(0.0000)\end{array}$ & $\begin{array}{c}33.87 \\
(0.0000)\end{array}$ & $\begin{array}{c}34.16 \\
(0.0000)\end{array}$ & $\begin{array}{c}3.40 \\
(0.0653)\end{array}$ & $\begin{array}{c}96.46 \\
(0.0000)\end{array}$ & $\begin{array}{c}0.66 \\
(0.4148)\end{array}$ & $\begin{array}{c}3.69 \\
(0.0500)\end{array}$ & $\begin{array}{c}12.41 \\
(0.0000)\end{array}$ \\
\hline $\begin{array}{l}t \text {-stat2 } \\
\left(\mathrm{H}_{0}: \alpha_{3}=\alpha_{4}\right)\end{array}$ & $\begin{array}{c}29.12 \\
(0.0000)\end{array}$ & $\begin{array}{c}11.14 \\
(0.0008)\end{array}$ & $\begin{array}{c}20.92 \\
(0.0000)\end{array}$ & $\begin{array}{c}39.19 \\
(0.0000)\end{array}$ & $\begin{array}{l}35.13 \\
(0.0000)\end{array}$ & $\begin{array}{c}50.24 \\
(0.0000)\end{array}$ & $\begin{array}{c}54.97 \\
(0.0000)\end{array}$ & $\begin{array}{c}31.49 \\
(0.0000)\end{array}$ & $\begin{array}{c}34.51 \\
(0.0000)\end{array}$ & $\begin{array}{c}10.27 \\
(0.0000)\end{array}$ & $\begin{array}{c}60.96 \\
(0.0000)\end{array}$ \\
\hline $\mathrm{R}^{2}$ & 0.3385 & 0.3207 & 0.4287 & 0.3310 & 0.5384 & 0.3564 & 0.3454 & 0.3457 & 0.3934 & 0.2850 & 0.4271 \\
\hline
\end{tabular}

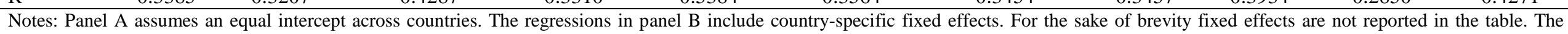
regressions are based on an unbalanced panel while the length of the series for each country is determined by data availability in Table $1 . P$-values are reported in parentheses. 
Table 3: Estimates of herding for the full sample period (equation 3).

\begin{tabular}{lccccccc}
\hline & Bangladesh & Egypt & Indonesia & Malaysia & Morocco & Pakistan & Turkey \\
\cline { 2 - 7 }$\alpha_{0}$ & 0.0139 & 0.0137 & 0.0162 & 0.0144 & 0.0067 & 0.0169 & 0.0157 \\
& $(0.0000)$ & $(0.0000)$ & $(0.0000)$ & $(0.0000)$ & $(0.0000)$ & $(0.0000)$ & $(0.0000)$ \\
$\alpha_{1}$ & 0.3135 & 0.2290 & 0.3837 & 0.3227 & 0.8849 & 0.0115 & 0.7195 \\
& $(0.0000)$ & $(0.0001)$ & $(0.0000)$ & $(0.0000)$ & $(0.0000)$ & $(0.8621)$ & $(0.0000)$ \\
$\alpha_{2}$ & 0.2385 & 0.2582 & 0.5609 & 0.4065 & 0.7023 & 0.3639 & 0.5525 \\
& $(0.0000)$ & $(0.0000)$ & $(0.0000)$ & $(0.0000)$ & $(0.0000)$ & $(0.0000)$ & $(0.0000)$ \\
$\alpha_{3}$ & -0.1661 & -0.9468 & -0.2861 & 0.8804 & -0.1573 & 0.9343 & -0.3772 \\
& $(0.0002)$ & $(0.0030)$ & $(0.0000)$ & $(0.0000)$ & $(0.0000)$ & $(0.0000)$ & $(0.0000)$ \\
$\alpha_{4}$ & 0.2282 & -0.8842 & -0.2064 & -0.1658 & 0.6005 & -0.1054 & -0.0706 \\
& $(0.0000)$ & $(0.0000)$ & $(0.0000)$ & $(0.0000)$ & $(0.0000)$ & $(0.0000)$ & $(0.0000)$ \\
$\mathrm{t}-\mathrm{stat}$ & -1.5154 & 0.4955 & 4.7643 & 3.7653 & -2.7226 & 5.4025 & -5.6539 \\
$\left(\mathrm{H}_{0}: \alpha_{1}=\alpha_{2}\right)$ & $(0.1297)$ & $(0.6203)$ & $(0.0000)$ & $(0.0002)$ & $(0.0065)$ & $(0.0000)$ & $(0.0000)$ \\
$\mathrm{t}-\mathrm{stat}$ & 4.2160 & 0.0409 & -0.5247 & -19.6039 & 7.0896 & -5.6246 & 10.4797 \\
$\left(\mathrm{H}_{0}: \alpha_{3}=\alpha_{4}\right)$ & $(0.0000)$ & $(0.9674)$ & $(0.5998)$ & $(0.0000)$ & $(0.0000)$ & $(0.0000)$ & $(0.0000)$ \\
$\mathrm{R}^{2}$ & 0.2688 & 0.0992 & 0.3075 & 0.3545 & 0.4823 & 0.1650 & 0.4179 \\
\hline
\end{tabular}

Notes: The table presents the estimates from the following equation:

$\operatorname{CSAD}_{\mathrm{t}}=\alpha_{0}+\alpha_{1} \mathrm{D}\left|\mathrm{r}_{\mathrm{m}, \mathrm{t}}\right|+\alpha_{2}(1-\mathrm{D})\left|\mathrm{r}_{\mathrm{m}, \mathrm{t}}\right|+\alpha_{3} \mathrm{Dr}_{\mathrm{m}, \mathrm{t}}^{2}+\alpha_{4}(1-\mathrm{D}) \mathrm{r}_{\mathrm{m}, \mathrm{t}}^{2}+\varepsilon_{\mathrm{t}}$

CSAD refers to the cross sectional absolute deviation of returns for each market. The equation is estimated using NeweyWest consistent estimators. D is a dummy assuming the value of one for the days falling within Ramadan each year, zero otherwise. P-values are reported in parentheses; the difference in significance between the within- versus outside-Ramadan values of each coefficient is tested using t-test statistics. $r_{m, t}$ refers to the each market's average return. 
Table 4: Estimates of herding for up versus down domestic market days (equations 4 and 5). Panel A: herding estimates for up domestic market days (equation 4)

\begin{tabular}{|c|c|c|c|c|c|c|c|}
\hline \multirow{3}{*}{$\alpha_{0}$} & Bangladesh & Egypt & Indonesia & Malaysia & Morocco & Pakistan & Turkey \\
\hline & 0.0144 & 0.0135 & 0.0158 & 0.0143 & 0.0062 & 0.0159 & 0.0134 \\
\hline & $(0.0000)$ & $(0.0000)$ & $(0.0000)$ & $(0.0000)$ & $(0.0000)$ & $(0.0000)$ & $(0.0000)$ \\
\hline \multirow[t]{2}{*}{$\alpha_{1}$} & 0.3503 & 0.2733 & 0.4115 & 0.2334 & 0.9427 & 0.1239 & 0.8526 \\
\hline & $(0.0005)$ & $(0.0112)$ & $(0.0000)$ & $(0.0000)$ & $(0.0000)$ & $(0.1583)$ & $(0.0000)$ \\
\hline \multirow[t]{2}{*}{$\alpha_{2}$} & 0.2597 & 0.2719 & 0.5946 & 0.4573 & 0.7304 & 0.4787 & 0.8475 \\
\hline & $(0.0000)$ & $(0.0000)$ & $(0.0000)$ & $(0.0000)$ & $(0.0000)$ & $(0.0000)$ & $(0.0000)$ \\
\hline \multirow[t]{2}{*}{$\alpha_{3}$} & -0.1880 & -0.0997 & -0.8760 & 0.2158 & -0.1776 & 0.6870 & -0.4828 \\
\hline & $(0.2527)$ & $(0.9815)$ & $(0.0000)$ & $(0.0000)$ & $(0.0002)$ & $(0.0064)$ & $(0.0000)$ \\
\hline \multirow[t]{2}{*}{$\alpha_{4}$} & 0.2006 & -0.8877 & -0.3061 & -0.2131 & 0.6248 & -0.1355 & -0.4515 \\
\hline & $(0.0000)$ & $(0.0000)$ & $(0.0000)$ & $(0.0000)$ & $(0.0000)$ & $(0.0000)$ & $(0.0000)$ \\
\hline t-stat ${ }_{1}$ & -0.9114 & -0.0134 & 4.0766 & 5.1894 & -2.3416 & 4.1306 & -0.1418 \\
\hline$\left(\mathrm{H}_{0}: \alpha_{1}=\alpha_{2}\right)$ & $(0.3621)$ & $(0.9893)$ & $(0.0000)$ & $(0.0000)$ & $(0.0193)$ & $(0.0000)$ & $(0.8872)$ \\
\hline t-stat 2 & 1.2683 & -0.1836 & -13.2137 & -13.3006 & 5.0675 & -3.2798 & -0.8688 \\
\hline$\left(\mathrm{H}_{0}: \alpha_{3}=\alpha_{4}\right)$ & $(0.2048)$ & $(0.8543)$ & $(0.0000)$ & $(0.0000)$ & $(0.0000)$ & $(0.0010)$ & $(0.3850)$ \\
\hline $\mathrm{R}^{2}$ & 0.3046 & 0.1013 & 0.2826 & 0.3157 & 0.4998 & 0.2196 & 0.4724 \\
\hline
\end{tabular}

Panel B: herding estimates for down domestic market days (equation 5)

\begin{tabular}{|c|c|c|c|c|c|c|c|}
\hline$\alpha_{0}$ & $\begin{array}{c}0.0124 \\
(0.0000)\end{array}$ & $\begin{array}{c}0.0137 \\
(0.0000)\end{array}$ & $\begin{array}{c}0.0176 \\
(0.0000)\end{array}$ & $\begin{array}{c}0.0148 \\
(0.0000)\end{array}$ & $\begin{array}{c}0.0073 \\
(0.0000)\end{array}$ & $\begin{array}{c}0.0180 \\
(0.0000)\end{array}$ & $\begin{array}{c}0.0175 \\
(0.0000)\end{array}$ \\
\hline$\alpha_{1}$ & $\begin{array}{c}0.3162 \\
(0.0000)\end{array}$ & $\begin{array}{c}0.1534 \\
(0.0842)\end{array}$ & $\begin{array}{c}0.3334 \\
(0.0000)\end{array}$ & $\begin{array}{c}0.2335 \\
(0.0000)\end{array}$ & $\begin{array}{c}0.8513 \\
(0.0000)\end{array}$ & $\begin{array}{l}-0.1106 \\
(0.2711)\end{array}$ & $\begin{array}{c}0.5573 \\
(0.0000)\end{array}$ \\
\hline$\alpha_{2}$ & $\begin{array}{c}0.3537 \\
(0.0000)\end{array}$ & $\begin{array}{c}0.2948 \\
(0.0000)\end{array}$ & $\begin{array}{c}0.4243 \\
(0.0000)\end{array}$ & $\begin{array}{c}0.3188 \\
(0.0000)\end{array}$ & $\begin{array}{c}0.6862 \\
(0.0000)\end{array}$ & $\begin{array}{c}0.2489 \\
(0.0000)\end{array}$ & $\begin{array}{c}0.3687 \\
(0.0000)\end{array}$ \\
\hline$\alpha_{3}$ & $\begin{array}{l}-0.1909 \\
(0.0000)\end{array}$ & $\begin{array}{c}0.0491 \\
(0.9791)\end{array}$ & $\begin{array}{c}-0.2504 \\
(0.0000)\end{array}$ & $\begin{array}{c}0.1017 \\
(0.0000)\end{array}$ & $\begin{array}{l}-0.1495 \\
(0.0003)\end{array}$ & $\begin{array}{c}0.1202 \\
(0.0000)\end{array}$ & $\begin{array}{l}-0.2384 \\
(0.0000)\end{array}$ \\
\hline$\alpha_{4}$ & $\begin{array}{l}-0.1660 \\
(0.0000)\end{array}$ & $\begin{array}{l}-0.1699 \\
(0.0000)\end{array}$ & $\begin{array}{c}0.9878 \\
(0.0000)\end{array}$ & $\begin{array}{l}-0.7964 \\
(0.0000)\end{array}$ & $\begin{array}{c}0.5053 \\
(0.0000)\end{array}$ & $\begin{array}{l}-0.7238 \\
(0.0000)\end{array}$ & $\begin{array}{c}0.1055 \\
(0.0000)\end{array}$ \\
\hline $\begin{array}{l}\text { t-stat }_{1} \\
\left(\mathrm{H}_{0}: \alpha_{1}=\alpha_{2}\right)\end{array}$ & $\begin{array}{c}0.6941 \\
(0.4877)\end{array}$ & $\begin{array}{c}1.6266 \\
(0.1040)\end{array}$ & $\begin{array}{c}1.9681 \\
(0.0492)\end{array}$ & $\begin{array}{c}2.9069 \\
(0.0037)\end{array}$ & $\begin{array}{l}-1.6062 \\
(0.1084)\end{array}$ & $\begin{array}{c}3.6456 \\
(0.0003)\end{array}$ & $\begin{array}{l}-3.3844 \\
(0.0007)\end{array}$ \\
\hline $\begin{array}{l}\text { t-stat } \\
\left(\mathrm{H}_{0}: \alpha_{3}=\alpha_{4}\right) \\
\mathrm{R}^{2}\end{array}$ & $\begin{array}{c}-0.5506 \\
(0.5820) \\
0.1434\end{array}$ & $\begin{array}{c}-0.9338 \\
(0.3505) \\
0.1020\end{array}$ & $\begin{array}{c}22.8741 \\
(0.0000) \\
0.6099\end{array}$ & $\begin{array}{c}-10.4988 \\
(0.0000) \\
0.4260\end{array}$ & $\begin{array}{c}4.7511 \\
(0.0000) \\
0.4656\end{array}$ & $\begin{array}{c}-4.7506 \\
(0.0000) \\
0.1147\end{array}$ & $\begin{array}{c}5.2255 \\
(0.0000) \\
0.4269\end{array}$ \\
\hline
\end{tabular}

Notes: The table presents the estimates from the following equations:

$\operatorname{CSAD}_{\mathrm{t}}=\alpha_{0}+\alpha_{1}{ }^{\mathrm{UP}} \mathrm{D}\left|\mathrm{r}_{\mathrm{m}, \mathrm{t}}\right|+\alpha_{2}{ }^{\mathrm{UP}}(1-\mathrm{D})\left|\mathrm{r}_{\mathrm{m}, \mathrm{t}}\right|+\alpha_{3}{ }^{\mathrm{UP}} \mathrm{Dr}_{\mathrm{m}, \mathrm{t}}^{2}+\alpha_{4}{ }^{\mathrm{UP}}(1-\mathrm{D}) \mathrm{r}_{\mathrm{m}, \mathrm{t}}^{2}+\varepsilon_{\mathrm{t}}$

$\mathrm{CSAD}_{\mathrm{t}}=\alpha_{0}+\alpha_{1}{ }^{\text {DOWN }} \mathrm{D}\left|\mathrm{r}_{\mathrm{m}, \mathrm{t}}\right|+\alpha_{2}{ }^{\text {DOWN }}(1-\mathrm{D})\left|\mathrm{r}_{\mathrm{m}, \mathrm{t}}\right|+\alpha_{3}{ }^{\text {DOWN }} \mathrm{Dr}_{\mathrm{m}, \mathrm{t}}^{2}+\alpha_{4}{ }^{\text {DOWN }}(1-\mathrm{D}) \mathrm{r}_{\mathrm{m}, \mathrm{t}}^{2}+\varepsilon_{\mathrm{t}}$

CSAD refers to the cross sectional absolute deviation of returns for each market. The equations are estimated using Newey-

West consistent estimators. D is a dummy assuming the value of one for the days falling within Ramadan each year, zero otherwise. P-values are reported in parentheses; the difference in significance between the within- versus outside-Ramadan values of each coefficient is tested using t-test statistics. $r_{m, t}$ refers to the each market's average return; The superscripts UP and DOWN denote that the model is estimated for days of positive ("up domestic market days") and negative ("down domestic market days") domestic market returns, respectively. 
Table 5: Estimates of herding for increasing versus decreasing domestic volume days (equations 6 and 7).

\begin{tabular}{|c|c|c|c|c|c|c|c|}
\hline \multicolumn{8}{|c|}{ Panel A: herding estimates for increasing domestic volume days (equation 6) } \\
\hline \multirow{3}{*}{$\alpha_{0}$} & Bangladesh & Egypt & Indonesia & Malaysia & Morocco & Pakistan & Turkey \\
\hline & 0.0142 & 0.0140 & 0.0162 & 0.0144 & 0.0066 & 0.0177 & 0.0163 \\
\hline & $(0.0000)$ & $(0.0000)$ & $(0.0000)$ & $(0.0000)$ & $(0.0000)$ & $(0.0000)$ & $(0.0000)$ \\
\hline \multirow[t]{2}{*}{$\alpha_{1}$} & 0.3531 & 0.1887 & 0.4450 & 0.3290 & 0.8974 & 0.0705 & 0.6521 \\
\hline & $(0.0000)$ & $(0.0482)$ & $(0.0000)$ & $(0.0000)$ & $(0.0000)$ & $(0.4384)$ & $(0.0000)$ \\
\hline \multirow[t]{2}{*}{$\alpha_{2}$} & 0.2384 & 0.1998 & 0.4935 & 0.4067 & 0.6890 & 0.3251 & 0.4535 \\
\hline & $(0.0000)$ & $(0.0000)$ & $(0.0000)$ & $(0.0000)$ & $(0.0000)$ & $(0.0000)$ & $(0.0000)$ \\
\hline \multirow[t]{2}{*}{$\alpha_{3}$} & -0.3645 & -0.1156 & -0.7234 & 0.8612 & -0.1591 & 0.3608 & -0.3522 \\
\hline & $(0.0000)$ & $(0.6853)$ & $(0.0000)$ & $(0.0000)$ & $(0.0003)$ & $(0.1688)$ & $(0.0000)$ \\
\hline \multirow[t]{2}{*}{$\alpha_{4}$} & -0.2410 & -0.6847 & -0.3304 & -0.1660 & 0.5561 & -0.9490 & 0.1292 \\
\hline & $(0.0000)$ & $(0.0000)$ & $(0.0000)$ & $(0.0000)$ & $(0.0000)$ & $(0.0000)$ & $(0.4663)$ \\
\hline t-stat ${ }_{1}$ & -1.9940 & 0.1188 & 1.2031 & 3.4538 & -2.2326 & 2.8568 & -4.7990 \\
\hline$\left(\mathrm{H}_{0}: \alpha_{1}=\alpha_{2}\right)$ & $(0.04627)$ & $(0.9055)$ & $(0.2290)$ & $(0.0006)$ & $(0.0257)$ & $(0.0043)$ & $(0.0000)$ \\
\hline t-stat ${ }_{2}$ & 3.8801 & 0.1655 & -9.5927 & -19.3595 & 4.8770 & -1.7426 & 9.8018 \\
\hline$\left(\mathrm{H}_{0}: \alpha_{3}=\alpha_{4}\right)$ & $(0.0001)$ & $(0.8685)$ & $(0.0000)$ & $(0.0000)$ & $(0.0000)$ & $(0.0815)$ & $(0.0000)$ \\
\hline $\mathrm{R}^{2}$ & 0.1336 & 0.0718 & 0.2522 & 0.3549 & 0.4869 & 0.1353 & 0.3921 \\
\hline \multicolumn{8}{|c|}{ Panel B: herding estimates for decreasing domestic volume days (equation 7) } \\
\hline \multirow[t]{2}{*}{$\alpha_{0}$} & 0.0136 & 0.0128 & 0.0166 & 0.0122 & 0.0067 & 0.0162 & 0.0145 \\
\hline & $(0.0000)$ & $(0.0000)$ & $(0.0000)$ & $(0.0000)$ & $(0.0000)$ & $(0.0000)$ & $(0.0000)$ \\
\hline \multirow[t]{2}{*}{$\alpha_{1}$} & 0.2804 & 0.3465 & 0.2759 & 0.0548 & 0.8777 & -0.0234 & 0.8127 \\
\hline & $(0.0000)$ & $(0.0000)$ & $(0.0000)$ & $(0.8337)$ & $(0.0000)$ & $(0.8105)$ & $(0.0000)$ \\
\hline \multirow[t]{2}{*}{$\alpha_{2}$} & 0.2335 & 0.4256 & 0.6088 & 0.4261 & 0.7285 & 0.4003 & 0.7608 \\
\hline & $(0.0000)$ & $(0.0000)$ & $(0.0000)$ & $(0.0466)$ & $(0.0000)$ & $(0.0000)$ & $(0.0000)$ \\
\hline \multirow[t]{2}{*}{$\alpha_{3}$} & -0.1008 & -0.2167 & -0.2084 & 0.2545 & -0.1568 & 0.1458 & -0.4044 \\
\hline & $(0.0245)$ & $(0.2404)$ & $(0.0000)$ & $(0.7369)$ & $(0.0002)$ & $(0.0000)$ & $(0.0000)$ \\
\hline \multirow[t]{2}{*}{$\alpha_{4}$} & 0.1099 & -0.2629 & 0.6868 & -0.2299 & 0.6735 & -0.1145 & -0.3017 \\
\hline & $(0.0000)$ & $(0.0000)$ & $(0.0000)$ & $(0.6125)$ & $(0.0000)$ & $(0.0000)$ & $(0.0000)$ \\
\hline t-stat ${ }_{1}$ & -0.9386 & 0.9914 & 6.5848 & 1.6056 & -1.5537 & 4.4249 & -1.1739 \\
\hline$\left(H_{0}: \alpha_{1}=\alpha_{2}\right)$ & $(0.3480)$ & $(0.3216)$ & $(0.0000)$ & $(0.1149)$ & $(0.1204)$ & $(0.0000)$ & $(0.2405)$ \\
\hline t-stat 2 & 4.7212 & 0.2507 & 16.2522 & -0.6514 & 5.2511 & -6.0423 & 1.9421 \\
\hline$\left(\mathrm{H}_{0}: \alpha_{3}=\alpha_{4}\right)$ & $(0.0000)$ & $(0.8021)$ & $(0.0000)$ & $(0.5179)$ & $(0.0000)$ & $(0.0000)$ & $(0.0522)$ \\
\hline $\mathrm{R}^{2}$ & 0.7277 & 0.1521 & 0.6301 & 0.4364 & 0.4791 & 0.1972 & 0.4777 \\
\hline
\end{tabular}

Notes: The table presents the estimates from the following equations:

$\mathrm{CSAD}_{\mathrm{t}}=\alpha_{0}+\alpha_{1}{ }^{\mathrm{UPVol}} \mathrm{D}\left|\mathrm{r}_{\mathrm{m}, \mathrm{t}}\right|+\alpha_{2}{ }^{\mathrm{UPVol}}(1-\mathrm{D})\left|\mathrm{r}_{\mathrm{m}, \mathrm{t}}\right|+\alpha_{3}{ }^{\mathrm{UPVol}} \mathrm{Dr}_{\mathrm{m}, \mathrm{t}}^{2}+\alpha_{4}{ }^{\mathrm{UPVol}}(1-\mathrm{D}) \mathrm{r}_{\mathrm{m}, \mathrm{t}}^{2}+\varepsilon_{\mathrm{t}}$

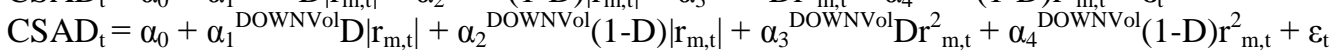

CSAD refers to the cross sectional absolute deviation of returns for each market. The equations are estimated using NeweyWest consistent estimators. D is a dummy assuming the value of one for the days falling within Ramadan each year, zero otherwise. P-values are reported in parentheses. The difference in significance between the within- versus outside-Ramadan values of each coefficient is tested using t-test statistics. $r_{m, t}$ refers to the each market's average return; The superscripts UPVol and DOWNVol denote that the model is estimated for days of increasing and decreasing market volume, respectively. 
Table 6: Estimates of herding for up versus down US market days (equations 8 and 9).

\begin{tabular}{|c|c|c|c|c|c|c|c|}
\hline \multicolumn{8}{|c|}{ Panel A: herding estimates for up US market days (equation 8) } \\
\hline & Bangladesh & Egypt & Indonesia & Malaysia & Morocco & Pakistan & Turkey \\
\hline \multirow[t]{2}{*}{$\alpha_{0}$} & 0.0139 & 0.0137 & 0.0169 & 0.0144 & 0.0067 & 0.0166 & 0.0141 \\
\hline & $(0.0000)$ & $(0.0000)$ & $(0.0000)$ & $(0.0000)$ & $(0.0000)$ & $(0.0000)$ & $(0.0000)$ \\
\hline \multirow[t]{2}{*}{$\alpha_{1}$} & 0.3611 & 0.2550 & 0.2442 & 0.3673 & 0.8905 & 0.1646 & 0.8193 \\
\hline & $(0.0000)$ & $(0.0006)$ & $(0.0000)$ & $(0.0000)$ & $(0.0000)$ & $(0.0745)$ & $(0.0000)$ \\
\hline \multirow[t]{2}{*}{$\alpha_{2}$} & 0.2192 & 0.2374 & 0.4735 & 0.3704 & 0.6864 & 0.3978 & 0.7621 \\
\hline & $(0.0000)$ & $(0.0000)$ & $(0.0000)$ & $(0.0000)$ & $(0.0000)$ & $(0.0000)$ & $(0.0000)$ \\
\hline \multirow[t]{2}{*}{$\alpha_{3}$} & -0.1484 & 0.1021 & -0.1856 & 0.7632 & -0.1508 & 0.3149 & -0.4047 \\
\hline & $(0.0278)$ & $(0.9531)$ & $(0.0000)$ & $(0.0000)$ & $(0.0000)$ & $(0.2656)$ & $(0.0000)$ \\
\hline \multirow[t]{2}{*}{$\alpha_{4}$} & 0.2773 & -0.7967 & 0.0850 & -0.1317 & 0.5703 & -0.1376 & -0.3817 \\
\hline & $(0.0000)$ & $(0.0000)$ & $(0.0460)$ & $(0.0000)$ & $(0.0000)$ & $(0.0000)$ & $(0.0000)$ \\
\hline t-stat ${ }_{1}$ & -1.9606 & -0.2411 & 4.7052 & 0.1080 & -2.4849 & 2.5761 & -1.3909 \\
\hline$\left(\mathrm{H}_{0}: \alpha_{1}=\alpha_{2}\right)$ & $(0.0500)$ & $(0.8095)$ & $(0.0000)$ & $(0.9140)$ & $(0.0130)$ & $(0.0100)$ & $(0.1643)$ \\
\hline t-stat ${ }_{2}$ & 2.6207 & -0.5189 & 5.1902 & -11.7850 & 5.7541 & 1.6027 & 1.8692 \\
\hline$\left(\mathrm{H}_{0}: \alpha_{3}=\alpha_{4}\right)$ & $(0.0088)$ & $(0.6038)$ & $(0.0000)$ & $(0.0000)$ & $(0.0000)$ & $(0.1091)$ & $(0.0638)$ \\
\hline $\mathrm{R}^{2}$ & 0.3074 & 0.1011 & 0.3589 & 0.4178 & 0.4597 & 0.1797 & 0.4485 \\
\hline \multicolumn{8}{|c|}{ Panel B: herding estimates for down US market days (equation 9) } \\
\hline \multirow[t]{2}{*}{$\alpha_{0}$} & 0.0127 & 0.0130 & 0.0155 & 0.0142 & 0.0067 & 0.0174 & 0.0166 \\
\hline & $(0.0000)$ & $(0.0000)$ & $(0.0000)$ & $(0.0000)$ & $(0.0000)$ & $(0.0000)$ & $(0.0000)$ \\
\hline \multirow[t]{2}{*}{$\alpha_{1}$} & 0.3013 & 0.4008 & 0.5513 & 0.6260 & 0.8892 & -0.1083 & 0.6297 \\
\hline & $(0.0000)$ & $(0.0003)$ & $(0.0000)$ & $(0.0000)$ & $(0.0000)$ & $(0.2743)$ & $(0.0000)$ \\
\hline \multirow[t]{2}{*}{$\alpha_{2}$} & 0.4039 & 0.4180 & 0.6595 & 0.4594 & 0.7243 & 0.3048 & 0.4624 \\
\hline & $(0.0000)$ & $(0.0000)$ & $(0.0000)$ & $(0.0000)$ & $(0.0000)$ & $(0.0000)$ & $(0.0000)$ \\
\hline \multirow[t]{2}{*}{$\alpha_{3}$} & -0.2187 & -0.8467 & 0.8886 & -0.8085 & -0.1840 & 0.1353 & -0.3424 \\
\hline & $(0.0000)$ & $(0.0096)$ & $(0.4530)$ & $(0.0000)$ & $(0.0017)$ & $(0.0000)$ & $(0.0000)$ \\
\hline \multirow[t]{2}{*}{$\alpha_{4}$} & -0.1236 & -0.3562 & -0.8102 & -0.2090 & 0.6114 & -0.6043 & 0.2428 \\
\hline & $(0.0000)$ & $(0.0000)$ & $(0.0000)$ & $(0.0000)$ & $(0.0000)$ & $(0.0000)$ & (0.1439) \\
\hline t-stat ${ }_{1}$ & 1.7086 & 0.1614 & 1.2682 & -2.6461 & -1.4212 & 4.2560 & -3.8426 \\
\hline$\left(\mathrm{H}_{0}: \alpha_{1}=\alpha_{2}\right)$ & $(0.0877)$ & $(0.8718)$ & $(0.2048)$ & $(0.0082)$ & $(0.1554)$ & $(0.0000)$ & $(0.0001)$ \\
\hline t-stat 2 & 1.8011 & 1.7103 & -1.4381 & 4.5625 & 4.1846 & -5.6440 & 9.5934 \\
\hline$\left(\mathrm{H}_{0}: \alpha_{3}=\alpha_{4}\right)$ & $(0.0718)$ & $(0.0911)$ & $(0.1505)$ & $(0.0000)$ & $(0.0000)$ & $(0.0000)$ & $(0.0000)$ \\
\hline $\mathrm{R}^{2}$ & 0.2200 & 0.1168 & 0.3111 & 0.2678 & 0.5066 & 0.1621 & 0.4131 \\
\hline
\end{tabular}

Notes: The table presents the estimates from the following equations:

$\mathrm{CSAD}_{\mathrm{t}}=\alpha_{0}+\alpha_{1}{ }^{\mathrm{UPUS}} \mathrm{D}\left|\mathrm{r}_{\mathrm{m}, \mathrm{t}}\right|+\alpha_{2}{ }^{\mathrm{UPUS}}(1-\mathrm{D})\left|\mathrm{r}_{\mathrm{m}, \mathrm{t}}\right|+\alpha_{3}{ }^{\mathrm{UPUS}} \mathrm{Dr}_{\mathrm{m}, \mathrm{t}}{ }^{2}+\alpha_{4}{ }^{\text {UPUS }}(1-\mathrm{D}) \mathrm{r}_{\mathrm{m}, \mathrm{t}}{ }^{2}+\varepsilon_{\mathrm{t}}$

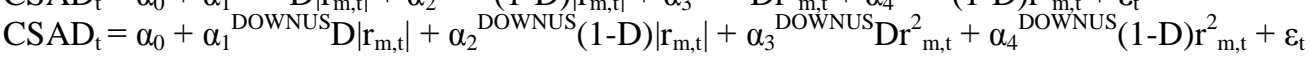

CSAD refers to the cross sectional absolute deviation of returns for each market. The equations are estimated using NeweyWest consistent estimators. D is a dummy assuming the value of one for the days falling within Ramadan each year, zero otherwise. $p$-values are reported in parentheses. The difference in significance between the within- versus outside-Ramadan values of each coefficient is tested using t-test statistics. $r_{\mathrm{m}, \mathrm{t}}$ refers to the each market's average return; The superscripts UPUS and DOWNUS denote that the model is estimated for days of positive ("up US market days") and negative ("down US market days") US market returns, respectively. 
Table 7: Estimates of herding for up versus down VIX days (equations 10 and 11).

\begin{tabular}{|c|c|c|c|c|c|c|c|}
\hline & Bangladesh & Egypt & Indonesia & Malaysia & Morocco & Pakistan & Turkey \\
\hline \multirow[t]{2}{*}{$\alpha_{0}$} & 0.0130 & 0.0137 & 0.0157 & 0.0144 & 0.0064 & 0.0171 & 0.0167 \\
\hline & $(0.0000)$ & $(0.0000)$ & $(0.0000)$ & $(0.0000)$ & $(0.0000)$ & $(0.0000)$ & $(0.0000)$ \\
\hline \multirow[t]{2}{*}{$\alpha_{1}$} & 0.2405 & 0.4052 & 0.3894 & 0.4769 & 1.0500 & -0.0642 & 0.6827 \\
\hline & $(0.0000)$ & $(0.0000)$ & $(0.0000)$ & $(0.0000)$ & $(0.0000)$ & $(0.5093)$ & $(0.0000)$ \\
\hline \multirow[t]{2}{*}{$\alpha_{2}$} & 0.3703 & 0.2579 & 0.6377 & 0.4228 & 0.7584 & 0.3248 & 0.4782 \\
\hline & $(0.0000)$ & $(0.0000)$ & $(0.0000)$ & $(0.0000)$ & $(0.0000)$ & $(0.0000)$ & $(0.0000)$ \\
\hline \multirow[t]{2}{*}{$\alpha_{3}$} & -0.1269 & -0.8988 & -0.8613 & -0.4614 & -0.2363 & 0.1166 & -0.3663 \\
\hline & $(0.0030)$ & $(0.0029)$ & $(0.0000)$ & $(0.0000)$ & $(0.0000)$ & $(0.0000)$ & $(0.0000)$ \\
\hline \multirow[t]{2}{*}{$\alpha_{4}$} & -0.1253 & -0.8264 & -0.2899 & -0.1384 & 0.4163 & 0.6370 & -0.0356 \\
\hline & $(0.0000)$ & $(0.0000)$ & $(0.0000)$ & $(0.0000)$ & $(0.0000)$ & $(0.0000)$ & $(0.8385)$ \\
\hline t-stat ${ }_{1}$ & 2.3018 & 1.4932 & 5.0704 & -1.2072 & -2.6731 & 4.0875 & -4.6024 \\
\hline$\left(H_{0}: \alpha_{1}=\alpha_{2}\right)$ & $(0.0214)$ & $(0.1355)$ & $(0.0000)$ & $(0.2274)$ & $(0.0076)$ & $(0.0000)$ & $(0.0000)$ \\
\hline $\mathrm{t}$-stat 2 & 3.7301 & 2.7094 & -11.7731 & 5.4385 & 4.8887 & -5.2089 & 9.1342 \\
\hline$\left(\mathrm{H}_{0}: \alpha_{3}=\alpha_{4}\right)$ & $(0.0000)$ & $(0.0068)$ & $(0.0000)$ & $(0.0000)$ & $(0.0000)$ & $(0.0000)$ & $(0.0000)$ \\
\hline $\mathrm{R}^{2}$ & 0.1817 & 0.1043 & 0.3032 & 0.2887 & 0.4841 & 0.1745 & 0.3978 \\
\hline \multicolumn{8}{|c|}{ Panel B: herding estimates for down VIX days (equation 11) } \\
\hline \multirow[t]{2}{*}{$\alpha_{0}$} & 0.0134 & 0.0131 & 0.0169 & 0.0143 & 0.0069 & 0.0169 & 0.0144 \\
\hline & $(0.0000)$ & $(0.0000)$ & $(0.0000)$ & $(0.0000)$ & $(0.0000)$ & $(0.0000)$ & $(0.0000)$ \\
\hline \multirow[t]{2}{*}{$\alpha_{1}$} & 0.4396 & 0.2576 & 0.5303 & 0.4573 & 0.8059 & 0.1968 & 0.7446 \\
\hline & $(0.0000)$ & $(0.0014)$ & $(0.0000)$ & $(0.0000)$ & $(0.0000)$ & $(0.0640)$ & $(0.0000)$ \\
\hline \multirow[t]{2}{*}{$\alpha_{2}$} & 0.2802 & 0.3343 & 0.4557 & 0.4182 & 0.6600 & 0.3803 & 0.6953 \\
\hline & $(0.0000)$ & $(0.0000)$ & $(0.0000)$ & $(0.0000)$ & $(0.0000)$ & $(0.0000)$ & $(0.0000)$ \\
\hline \multirow[t]{2}{*}{$\alpha_{3}$} & -0.2180 & 0.2479 & -0.3784 & 0.5656 & -0.1083 & 0.1243 & -0.3748 \\
\hline & $(0.2020)$ & $(0.8938)$ & $(0.0001)$ & $(0.0000)$ & $(0.0063)$ & $(0.7459)$ & $(0.0000)$ \\
\hline \multirow[t]{2}{*}{$\alpha_{4}$} & 0.1972 & -0.2047 & 0.8489 & -0.2171 & 0.7800 & -0.1299 & -0.2706 \\
\hline & $(0.0000)$ & $(0.0000)$ & $(0.0000)$ & $(0.0000)$ & $(0.0000)$ & $(0.0000)$ & $(0.0000)$ \\
\hline t-stat ${ }_{1}$ & -1.5854 & 0.9767 & -1.0078 & -1.2671 & -1.6432 & 1.7572 & -1.1775 \\
\hline$\left(\mathrm{H}_{0}: \alpha_{1}=\alpha_{2}\right)$ & $(0.1130)$ & $(0.3288)$ & $(0.3136)$ & $(0.2052)$ & $(0.1005)$ & $(0.0790)$ & $(0.2391)$ \\
\hline t-stat 2 & 1.3942 & -1.2380 & 4.8079 & -15.9713 & 4.6808 & 0.6635 & 1.9840 \\
\hline$\left(\mathrm{H}_{0}: \alpha_{3}=\alpha_{4}\right)$ & $(0.1634)$ & $(0.2158)$ & $(0.0000)$ & $(0.0000)$ & $(0.0000)$ & $(0.5071)$ & $(0.0473)$ \\
\hline $\mathrm{R}^{2}$ & 0.3318 & 0.1113 & 0.5527 & 0.4406 & 0.4973 & 0.1654 & 0.4514 \\
\hline
\end{tabular}

Notes: The table presents the estimates from the following equations:

$\operatorname{CSAD}_{\mathrm{t}}=\alpha_{0}+\alpha_{1}{ }^{\mathrm{UPVIX}} \mathrm{D}\left|\mathrm{r}_{\mathrm{m}, \mathrm{t}}\right|+\alpha_{2}{ }^{\mathrm{UPVIX}}(1-\mathrm{D})\left|\mathrm{r}_{\mathrm{m}, \mathrm{t}}\right|+\alpha_{3}{ }^{\mathrm{UPVIX}} \mathrm{Dr}_{\mathrm{m}, \mathrm{t}}^{2}+\alpha_{4}{ }^{\mathrm{UPVIX}}(1-\mathrm{D}) \mathrm{r}_{\mathrm{m}, \mathrm{t}}^{2}+\varepsilon_{\mathrm{t}}$

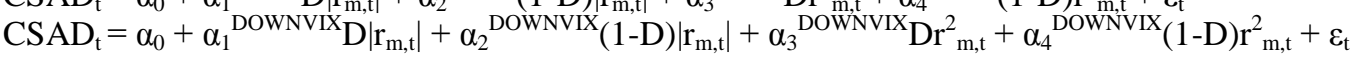

CSAD refers to the cross sectional absolute deviation of returns for each market. The equations are estimated using NeweyWest consistent estimators. D is a dummy assuming the value of one for the days falling within Ramadan each year, zero otherwise. p-values are reported in parentheses. The difference in significance between the within- versus outside-Ramadan values of each coefficient is tested using t-test statistics. $r_{m, t}$ refers to the each market's average return; The superscripts UPVIX and DOWNVIX denote that the model is estimated for days of increasing and decreasing VIX values, respectively. 
Table 8: Estimates of herding before and after the crisis' outbreak (equations 12 and 13).

\begin{tabular}{|c|c|c|c|c|c|c|c|}
\hline \multicolumn{8}{|c|}{ Panel A: herding estimates pre outbreak (equation 12) } \\
\hline & Bangladesh & Egypt & Indonesia & Malaysia & Morocco & Pakistan & Turkey \\
\hline \multirow[t]{2}{*}{$\alpha_{0}$} & 0.0126 & 0.0140 & 0.0154 & 0.0134 & 0.0054 & 0.0157 & 0.0168 \\
\hline & $(0.0000)$ & $(0.0000)$ & $(0.0000)$ & $(0.0000)$ & $(0.0000)$ & $(0.0000)$ & $(0.0000)$ \\
\hline \multirow[t]{2}{*}{$\alpha_{1}$} & 0.4425 & 0.2476 & 0.6289 & 0.3473 & 1.0512 & -0.0182 & 0.7703 \\
\hline & $(0.0000)$ & $(0.0538)$ & $(0.0000)$ & $(0.0000)$ & $(0.0000)$ & $(0.8147)$ & $(0.0000)$ \\
\hline \multirow[t]{2}{*}{$\alpha_{2}$} & 0.3040 & 0.3024 & 0.6701 & 0.4243 & 0.8012 & 0.3839 & 0.5530 \\
\hline & $(0.0000)$ & $(0.0000)$ & $(0.0000)$ & $(0.0000)$ & $(0.0000)$ & $(0.0000)$ & $(0.0000)$ \\
\hline \multirow[t]{2}{*}{$\alpha_{3}$} & -0.2295 & -0.4183 & -0.4737 & 0.8176 & -0.2470 & 0.1132 & -0.6679 \\
\hline & $(0.0000)$ & $(0.9460)$ & $(0.0000)$ & $(0.0000)$ & $(0.0000)$ & $(0.0000)$ & $(0.0000)$ \\
\hline \multirow[t]{2}{*}{$\alpha_{4}$} & 0.1368 & -0.9978 & -0.4628 & -0.1360 & 0.5465 & -0.1075 & -0.4101 \\
\hline & $(0.0000)$ & $(0.0000)$ & $(0.0000)$ & $(0.0000)$ & $(0.0000)$ & $(0.0000)$ & $(0.0000)$ \\
\hline t-stat ${ }_{1}$ & -2.1588 & 0.4340 & 0.8091 & 3.3500 & -2.8750 & 5.2821 & -6.3829 \\
\hline$\left(\mathrm{H}_{0}: \alpha_{1}=\alpha_{2}\right)$ & $(0.0309)$ & $(0.6643)$ & $(0.4185)$ & $(0.0008)$ & $(0.0041)$ & $(0.0000)$ & $(0.0000)$ \\
\hline t-stat 2 & 4.5365 & -0.0938 & -0.2268 & 15.5397 & 6.1571 & -5.6812 & 10.5347 \\
\hline$\left(\mathrm{H}_{0}: \alpha_{3}=\alpha_{4}\right)$ & $(0.0000)$ & $(0.9252)$ & $(0.8206)$ & $(0.0000)$ & $(0.0000)$ & $(0.0000)$ & $(0.0000)$ \\
\hline $\mathrm{R}^{2}$ & 0.3007 & 0.1107 & 0.3512 & 0.4346 & 0.5682 & 0.1912 & 0.4122 \\
\hline \multicolumn{8}{|c|}{ Panel B: herding estimates post outbreak (equation 13) } \\
\hline \multirow[t]{2}{*}{$\alpha_{0}$} & 0.0174 & 0.0123 & 0.0165 & 0.0175 & 0.0112 & 0.0194 & 0.0141 \\
\hline & $(0.0000)$ & $(0.0000)$ & $(0.0000)$ & $(0.0000)$ & $(0.0000)$ & $(0.0000)$ & $(0.0000)$ \\
\hline \multirow[t]{2}{*}{$\alpha_{1}$} & 0.0467 & 0.2550 & 0.3636 & 0.3168 & 0.3236 & 0.1782 & 0.2355 \\
\hline & $(0.4627)$ & $(0.0023)$ & $(0.0000)$ & $(0.0147)$ & $(0.0000)$ & $(0.1353)$ & $(0.0000)$ \\
\hline \multirow[t]{2}{*}{$\alpha_{2}$} & 0.1407 & 0.2482 & 0.4782 & 0.3211 & 0.3479 & 0.4501 & 0.2889 \\
\hline & $(0.0000)$ & $(0.0000)$ & $(0.0000)$ & $(0.0000)$ & $(0.0000)$ & $(0.0000)$ & $(0.0000)$ \\
\hline \multirow[t]{2}{*}{$\alpha_{3}$} & -0.2010 & -0.1036 & -0.4826 & -0.4029 & -0.5381 & 0.2857 & -0.3662 \\
\hline & $(0.0502)$ & $(0.5522)$ & $(0.0000)$ & $(0.3841)$ & $(0.8636)$ & $(0.3683)$ & $(0.3987)$ \\
\hline \multirow[t]{2}{*}{$\alpha_{4}$} & -0.1133 & -0.1178 & -0.3626 & -0.2639 & 0.1233 & -0.2444 & -0.7424 \\
\hline & $(0.0013)$ & $(0.0023)$ & $(0.0000)$ & $(0.0000)$ & $(0.5627)$ & $(0.0000)$ & $(0.0028)$ \\
\hline t-stat ${ }_{1}$ & 1.5256 & -0.0835 & 2.1721 & 0.0341 & 0.3025 & 2.3431 & 1.6520 \\
\hline$\left(\mathrm{H}_{0}: \alpha_{1}=\alpha_{2}\right)$ & $(0.1273)$ & $(0.9335)$ & $(0.0300)$ & $(0.9728)$ & $(0.7623)$ & $(0.0193)$ & $(0.0988)$ \\
\hline t-stat ${ }_{2}$ & 0.8410 & -0.0823 & -2.0698 & 0.3015 & 0.5058 & -1.6792 & -0.7957 \\
\hline$\left(\mathrm{H}_{0}: \alpha_{3}=\alpha_{4}\right)$ & $(0.4005)$ & $(0.9344)$ & $(0.0386)$ & $(0.7631)$ & $(0.6130)$ & $(0.0933)$ & $(0.4263)$ \\
\hline $\mathrm{R}^{2}$ & 0.0381 & 0.1173 & 0.1783 & 0.0950 & 0.2117 & 0.1544 & 0.4364 \\
\hline
\end{tabular}

Notes: The table presents the estimates from the following equations:

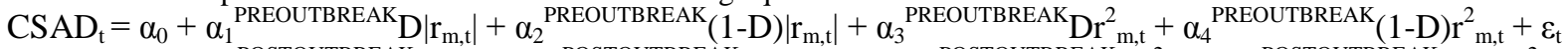

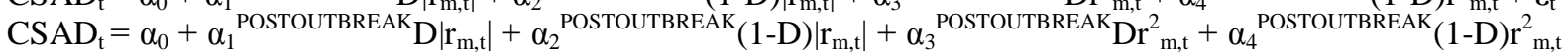
$+\varepsilon_{\mathrm{t}}$

CSAD refers to the cross sectional absolute deviation of returns for each market. The equations are estimated using NeweyWest consistent estimators. D is a dummy assuming the value of one for those days falling within Ramadan each year, zero otherwise. P-values are reported in parentheses. The difference in significance between the within- versus outside-Ramadan values of each coefficient is tested using t-test statistics. $r_{m, t}$ refers to the each market's average return; The superscripts PREOUTBREAK and POSTOUTBREAK denote that the model is estimated prior to and after the outbreak of the crisis, respectively. 